\title{
The Ethics and Dilemmas of Preventive Detention
}

\author{
By Geetanjali Swati Bhim
}

A thesis submitted to Victoria University of Wellington in fulfilment of the requirements for the degree of Master of Arts in Criminology

January 2017 


\begin{abstract}
There has been a considerable increase in the use of preventive sentencing in New Zealand since the mid-1980s. It has become widely accepted across Western society that preventive sentencing and supervision regimes are needed to protect the public from dangerous offenders. This thesis examines whether the development and use of preventive sentencing regimes is ethically justified, and if not what changes need to be made in order to alleviate some of the ethical dilemmas associated with indeterminate sentencing regimes. Preventive detention practices in Australia the UK and the US are reviewed to establish general practice regarding the development of legislation, use of risk assessment and the detention of dangerous offenders. This is compared to New Zealand practices, through research and analysis of three preventive detainee case files. The files confirm that the ethics of preventive detention has shifted from protecting the rights of individual offenders to protecting the public from them.
\end{abstract}




\section{Acknowledgements}

I would like to thank Professor John Pratt for agreeing to supervise this thesis and for seeing it through to the end. I would also like to say thank you to Dr Tony Ellis for his wisdom and guidance during the early years of this work.

Next, I had a number of very kind and understanding managers, across three different workplaces, during the course of my thesis. Thank you all for always being supportive and allowing me to take time off when I needed it to get work done.

Finally, my family: mummy and papa (Sashi and Ghanendra Bhim), my siblings Shilpa Bhim, Bhavana Bhim, Gaurav Bhim and my wonderful fiancé Jared Walton. Thank you for constantly being my rock and supporting me through this whole process. Without your love and support, this thesis would not have been possible. Thank you for always believing in me. 


\section{Contents}

$\begin{array}{ll}\text { Abstract } & \text { ii }\end{array}$

Acknowledgements

Contents

$\begin{array}{ll}\text { Chapter One: Introduction } & 1\end{array}$

Chapter Two: The Evolution of Preventive Sentencing in New 7 Zealand

Chapter Three: The Rise and Development of Actuarial Risk for Dangerousness

Chapter Four: Detaining the Dangerous

Chapter Five: Preventive Detention - How Does it Work in 64 New Zealand

Chapter Six: Conclusion

References

Appendix A: Crime Trends in New Zealand 


\section{Chapter One: Introduction}

New Zealand has one of the highest imprisonment rates amongst Western societies, well ahead of England and Australia, the countries with which it is most closely associated. ${ }^{1}$ This is a trend which has been increasing since the 1990s, despite the fact that New Zealand's recorded crime rate has been declining over the same time period (Pratt, 2013). ${ }^{2}$

There have been a number of policy and legislative changes since the late 1990s to introduce community-based sentences, increased use of fines and other alternative measures as a means to reduce New Zealand's prison rates. However, at the same time, there has been a steady increase in the use of harsher sentencing for more serious crimes, tightening of the use of parole and bail, and steady expansion of indeterminate sentencing laws. The result of this assortment of penal policy changes has been offenders being sent to prison for much longer and an increase in the number of offenders serving a life sentence or an indeterminate preventive sentence. The number of prisoners serving an indeterminate sentence ${ }^{3}$ in New Zealand has increased about two percent from 2010. There were 283 prisoners serving a preventive detention sentence in 2016, an increase from only 15 in 1981.

Such developments are a marked reversal of previous expectations for penal development in this country. In 1981, the Minister of Justice approved the establishment of a Penal Policy Review Committee (the Committee) to investigate concerns about crime in the community, and provide recommendation for changes. However, the subsequent report, published late that same year,

\footnotetext{
${ }^{1}$ New Zealand's has 208 prisoners per 100,000 of the population, whereas the United Kingdom (England and Wales) and Australia have 145 and 162 prisoners per 100,00 of the population respectively, as at September 2016: http://www.prisonstudies.org/country/new-zealand

${ }^{2}$ See Appendix A for graph which shows the decline in recorded offences in New Zealand from $1994-2012$.

${ }^{3}$ This includes both preventive detention and life sentences with no parole date.
} 
recommended that penal policy needed to be structured to reduce the number of offenders in prison - this was the essential problem that needed addressing, rather than crime itself. The Committee suggested this could be achieved by legislating for more community-based sanctions, especially for those offenders committing minor crimes. The Committee also recommended the wider use of probation in place of imprisonment as another means to manage offenders. In effect, these recommendations were reflective of the last remnants of social welfare in penal policy. The prison was not to be used as a means to contain and control social disorder and insecurities (Wacquant, 2001): instead, it was itself at this point seen as a 'last resort' penal option.

Of particular note from the Committee's report were the specific recommendations and comments regarding preventive detention. The Committee argued for the abolition of the sentence because of its minimal use and concerns arising as to the arbitrary use of it:

"This is the last sentence designed explicitly for the protection of the public and is the successor of earlier legislation which applied to a far wider range of offenders. It is now limited to any offender aged at least 25 who, having been convicted on at least one occasion since 17 of a specified sexual offence, receives a further conviction for such an offence. Its effect is equivalent to a life sentence, being indeterminate with first eligibility for parole after a period of 7 years. It is now rarely used, with only 15 inmates currently serving it. There are a number of criticisms. There is no rationale for its restriction to this group of offenders, and there are indications that its use is arbitrary, selective, and inequitable. Under section 33A(7) of the Criminal Justice Act 1954, the Parole Board cannot recommend release unless it is of the opinion that the inmate is not likely to continue to commit sexual crimes. Given the difficulties of making accurate predictions of human behaviour, this is bound to lead to 
administrative caution, and therefore to disproportionately long periods of detention. There has been a number of responsible submissions for its abolition on the basis that a determinate prison sentence, taking into account the principles we have already mentioned, should be used for these offenders.

The committee recognise that there is a strong case to abolish preventive detention, provided that a lengthy finite prison sentence can be imposed in appropriate cases where there is a continuing disposition and history of serious sexual or violent offending, and where the court is satisfied that there is a strong risk of repeated offending, and the protection of the public requires it. It recommends accordingly."

There are two points to note from the excerpt of the report above. First, the Committee found "no rationale for the restriction [of the sentence] to this group of offenders". The 1967 amendment to the Criminal Justice Act had abolished preventive detention for all offences except for sexual offending. Prior to the 1967 amendment, preventive detention was applicable to all recidivist offenders the majority of whom were property offenders. However, the Committee saw the enactment of the 1967 amendments as arbitrary guidelines in a pragmatic attempt to restrict the use of the sentence. Hence there was no ethical rationale for the provision to remain.

Second, the Committee made reference to "the difficulties of making accurate predictions of human behaviour", indicating support for the scepticism surrounding the use of clinical risk assessments at this time. The ability of psychologists to accurately predict an offender's risk of future criminal acts had been criticised by many as inefficient and inaccurate (see Pratt, 1996; Simon, 2005). Research indicated that psychologists would be cautious in their predictions, thus falling into a tendency to over predict dangerousness (Pratt, 
1996). This not only led to the unjust indeterminate sentencing of offenders, but also raised concerns about expending significant State resources on imprisonment when, as noted, it had come to be seen as a 'last resort' option (Pratt, 1996).

It was this lack of confidence in the abilities of clinical assessments and the arbitrary nature of the legislative enactments that formed the Committee's recommendation that Government should abolish preventive detention sentencing in New Zealand.

The Committee's recommendations formed the basis of what Brown and Young (2000) describe as, " $a$ fundamental rewrite of the country's then 30-year-old sentencing and penal administration legislation" which resulted in the enactment of the Criminal Justice Act 1985.

However, despite the 'fundamental rewrite', preventive detention was not abolished in the subsequent 1985 Criminal Justice Act. There, its provision was maintained, including the arbitrary guidelines on its use: only offenders over the age of 25 who repeatedly commit certain sexual offences could be sentenced to preventive detention. In essence, preventive detention remained in full as a sentencing option, at least for the very narrow and highly specific group of offenders it targeted at that time. There are two reasons, seemingly ${ }^{4}$, that explain why the Government of the day made the decision to keep preventive detention. First, there were anxieties related to a number of violent crimes during the 1980s (Meek, 1995) abolishing the most severe penal response to those crimes might have served to heighten them. Second, the Department of Justice commented, pragmatically, that if preventive detention was rarely used and when used only on a small number of the worst offenders, then there was no harm in the provision remaining as such (Meek, 1995). By this juncture, preventive detention had

\footnotetext{
${ }^{4}$ There is no commentary relating to preventive detention in Hansard debates and neither was there any public comment made by the Government (Meek, 1995).
} 
become a means of assuring the New Zealand public that the Government would protect its most vulnerable members from serious sexual offenders.

However, since 1985, the use of preventive detention has grown exponentially, assisted by various amendments to legislation which relaxed the qualifying restrictions. The increase in the use of preventive detention since then has occurred despite academic research across Western countries finding that preventive detention does not serve the purpose for which it was established (Harrison, 2011; Keyzer and Blay, 2006; McSherry, 2013). Preventive detention has not been proven to reduce violent or sexual offending. Similarly, it has no deterrent effect and it does not 'protect' society from offenders who are considered dangerous (Keyzer and Blay, 2006; McSherry, 2013). In addition to this, there are strong ethical arguments against the use of preventive sentencing as it denies fundamental rights such as liberty and autonomy on the premise of a prediction of a future possible offence and there is no foundation in punishment theory which validates imprisonment for a crime which has not yet been committed (von Hirsh 1976, cited in Floud and Young, 1981; McSherry, 2013)

This thesis will examine the development and use of preventive detention in New Zealand. It will consider how and on what basis, preventive detention has become justifiable as a sentence, given the numbers now serving this sentence when, in 1981, it had clearly become an unjustifiable sentencing practice. Chapter Two will provide a backdrop of policy and legislative development of preventive sentencing in New Zealand. This will highlight how preventive detention has become much more central to the New Zealand justice system despite continued ethical concerns with the use of such sentencing provisions. The ethical issues with preventive detention remain embedded in the argument that penal policy should not be developed on the premise of future offending. This is despite technological advancements and the rise in statistical analysis of criminal behaviour (Feeley and Simon 1992; Simon 2005). 
Chapter Three will analyse the development towards actuarial methods for risk assessment, where statistical methods are used to predict future likelihood of committing a crime rather than the heavily criticised clinical method previously used. Although there continues to be use of clinical psychologist's reports, judges and the Parole Board now consider these reports alongside other, more 'scientific' and statistical, reports based on actuarial prediction. However, it will be argued that the main problem with preventive detention provisions remain. They continue to be based on the unethical grounds of punishing an offender for a likely future crime rather than a crime that has been committed.

Chapter Four will investigate the trend across Western countries of the proliferation in indeterminate penal provisions in an attempt to protect society from 'dangerous' offenders. This chapter will explore how such policy and law is developed, whether or not there is a critical evaluation of the ever popular preventive and protective sentencing in New Zealand, and whether these provisions withstand ethical scrutiny. New Zealand's model of preventive detention will be compared to other Western nations, specifically the United Kingdom and the United States.

Chapter Five will provide a case study of three preventive detention cases in New Zealand. This chapter will summarise how preventive detention provisions work in practice, compare this to international case law and address the ethical issues that have been discussed in previous chapters.

Chapter Six summaries the themes that are evident through Chapters One to Five and concludes whether New Zealand's use of preventive detention is ethically justified and recommends improvements to the use of risk assessment and how offenders are detained. 


\section{Chapter Two: The Evolution of Preventive Sentencing in New Zealand}

Dangerousness and the dangerous offender have been problematic concepts within criminology and modern criminal justice systems since the end of the $19^{\text {th }}$ century. Dangerousness itself is a socially constructed concept which changes historically. From initial dangerous offender legislation at the end of the $19^{\text {th }}$ century, the accepted meaning of dangerousness has shifted from repeat property offenders, ${ }^{5}$ to homosexuals and pederasts in the mid- $20^{\text {th }}$ century, to sexual offending against women and children, to the present day where the focus is on offenders who commit any serious violent or sexual crime (Pratt, 1996; 1997; 1998). However, no matter what the concept of dangerous is at any particular point in time, those judged to be 'dangerous' in the penological sense of the term - that is, offenders who were not legally insane but kept repeating serious crimes (Pratt 1995) - have been dealt with by the criminal justice system via some form of preventive indeterminate sentencing from the late $19^{\text {th }}$ century to the present time.

However, preventive sentencing laws were initially intended to be a very rarely used sentence due to the concept so strongly breaching the principles of the modern criminal justice system, as it was a sentence which punished as offender for a future crime, rather than once which had already been committed (Pratt, 1996). This trend continued during the post-war period, when penal policy was based on a welfare ideal meaning the role of the State was to assist in the rehabilitation and reintegration of prisoners back into society (Harrison, 2011). Offenders were treated as individuals who were able to redeem negative characteristics and focus on their re-integration efforts (Garland, 2001). Regardless, as it remained a sentencing provision, academics were voicing ethical concerns with it as it was founded on a predicted risk of future harm, and even

\footnotetext{
${ }^{5}$ The Habitual Offenders Act 1906 marked the beginning of dangerous offender laws in the UK.
} 
more so as the sentence would impinge on a fundamental right to liberty, or freedom from arbitrary detention (Hannah-Moffat, 2013).

Court decisions and sentencing trends in the 1960s indicated that the sentence may have been on the road to abolition once and for all, especially with the United States Supreme Court decision of Baxstrom v Herold. ${ }^{6}$

This case considered the constitutional validity of a statutory procedure under which Baxstrom was committed to a mental institution after serving a criminal sentence for 'second degree assault'. While serving his time, Baxstrom was found insane and consequently transferred from prison to an institution which was under the control of the New York Department of Corrections. Close to the end of Baxstrom's period of imprisonment, the Hospital Director filed a petition for Baxstrom to be civilly committed, which was granted.

Although the place of custody had shifted from penal to medical institution, Baxstrom continued to be detained under the authority of the Department of Corrections. Baxstrom had challenged his detainment numerous times, but it was not until the Supreme Court appeal that a pivotal decision was made. The Court found a breach in the procedure for determining civil commitment and whether or not Baxstrom was in fact 'mentally ill' as set out in law.

Section 384 of the New York Corrections law allowed for civil commitment at the end of a penal term for mentally ill persons to be confined as they were considered dangerous. However, the law also provided that any person who was not satisfied with an insanity order made against them had the right to request a full review by a jury. If a jury determined that the individual was not insane then the individual had to be released immediately. The Court also made the point that there were different privileges under penal provisions and mental health care

\footnotetext{
${ }^{6}$ Baxstrom v. Herold, 383 U.S. 107 (1966).
} 
facility provisions and, in this case, a judicial proceeding which the State had specifically legislated for cannot be denied. This case indicated an ethical and rights-based approach was important for judges when considering preventive sentencing.

Following on from this decision (and other successful appeals from unlawfully detained persons) research was conducted into the patients who were released from the same prison/hospital as Baxstrom (collectively referred to as the Baxstrom patients, see Steadman, 1973). Steadman's (1973) research looked into what happened to the Baxstrom patients who were transferred from criminal to civil facilities. The research considered why they had been transferred, how much trouble the patients had caused, and whether there were any problems when the patients were released into the community.

Steadman (1973) found a number of interesting implications from the Baxstrom scenario. The most significant of these was that the Baxstrom patients were not, in fact, particularly 'dangerous'. This was because the majority of them had not caused much harm to themselves or to others (Steadman, 1973). Baxstrom himself was imprisoned only after conviction of second degree assault in New York. It seems his issue was more his mental health (Steadman, 1973). In addition, Steadman (1973) found that psychologists were unable to accurately make 'predictions' of future offending and nor were the validity of psychologist predictions grounded in any empirical data. This research and others like it (see Monahan, Brodsky and Shan, 1981; Steadman 1980; and Steadman and Cocozza, 1980) concluded that psychologists' reports predicting dangerousness were not reliable and were overly conservative (Floud and Young, 1981; Steadman, 1973). It was these findings which influenced further research regarding the ethics of preventive detention, both for (Floud and Young 1981) and against (Bottoms and Brownsword 1982) its use as a method of criminal punishment. 
However, cautious and conservative predictions, more likely than not to lead to indefinite detention, of dangerous behaviours were, and continue to be, desired by the public and legislators (Black, 2011). These are usually at the cost of ethical considerations for the offender under scrutiny and quite often result in the imprisonment of many persons who are not dangerous, to prevent inadvertently releasing the few who may be dangerous (Black, 2011). It was research findings similar to this which triggered a review and overhaul of penal policy across Western societies in the 1970s (Simon, 2005).

From the 1980s onwards there was a political shift from the welfare state towards neo-liberalism in the development of penal policy (Pratt, 1996). This shift was observed through a change in emphasis from rehabilitation and reintegration of offenders to a more punitive-focused management and control of crime and criminals (Pratt, 2007). Initially, Robert Martinson's study (1974), in which he made the claim that "nothing works" with regard to prisoner rehabilitation, was instrumental in facilitating this shift.

Martinson's (1974) claim that prisoner rehabilitation did not work seemed to be picked up by politicians as the evidence that they had been looking for to guide penal policy toward a more punitive incapacitation path. Phelps (2011) has argued that the 1970s are thus regarded as a turning point in American penal history. It seemed that Martinson's study was a catalyst which triggered the movement away from rehabilitative penal ideals towards more retributive and incapacitation theories. Thereafter, the rise of penal populism, further encouraged a greater punitive policies, including increased use of preventive detention sentencing (Pratt, 2007). Penal populism is a concept 'embedded' (Pratt, 2007) in social structural and cultural changes in modern society resulting from the economic reforms on the 1980s, which resulted in feelings of insecurity and lack of trust in politicians. This resulted in outspoken members of the public and lobby groups having greater influence on governments, whilst at the same time weakened 
communications and the advisory relationship between governments and criminal justice professionals. The result was that the public, or at least those who claimed to speak on its behalf, had more input in Government policy instead of the experts and professionals who previously guided policy decisions (Pratt, 2007). It is on this basis that Bottoms (1995 cited in Pratt, 2007) has argued that penal populism is one of the four main influences of contemporary criminal justice and penal systems in modern society.

In addition, criticisms of the inaccuracy of clinical diagnosis paved the way for the development of actuarial prediction. Feeley and Simon (1992) refer to this change in penal policy as the 'new penology'. From the 1980s, this emerged as a dominant paradigm grounded in new and improved methods of risk assessment and focusing on the management of dangerous offenders, rather than punishing an individual for a crime. This new foundation for penal policy further legitimated resurgence in the use of preventive detention. It allowed clinical risk assessments to be improved as they involved a more statistical component where offenders could be grouped into different categories depending on prior history and other characteristics (Floud and Young, 1981; Hannah-Moffat, 2013).

However, these arguments regarding 'new and improved' offender risk assessments, seemingly oblivious of the unresolvable dilemma regarding predicting future harm, still could not address the ethical concerns that had been raised by the US Supreme Court in the Baxstrom decision. This was, that there is no sufficient basis or justification for imprisoning persons on the grounds that they may commit a certain type of offense in the future.

Nonetheless, the urgency of responding to dangerous offending was fuelled by media reporting, which roused public fears and anxieties of violent and sexual crime in particular (Pratt, 2007). The increase in media reporting was brought on by structural changes and the deregulation of media from the 1980s. From limited 
media coverage through state-owned broadcasting and television channels, there private televisions channels and satellite television was introduced, which resulted in a commercial market for household television and media coverage (Pratt, 2007). Consequently, sensationalised crime shows and media reports were used as a means for the media to create a profit (Pratt, 2007). This saw the shift in news reporting into a tabloid news format, where emotions of victims were used as the main components instead of statistics and facts (Pratt, 2007). From this, there was a development of populist government crime policy, as a response to what the public wanted (Pratt, 2007).

The result of this 'perfect storm' was the revival of preventive detention, which had up until the 1980s been a rarely used sentence, and a sentence condemned for its lack of theoretical grounding, with more political and public popularity than ever before. Judges were exhorted to use the sentence and their discretion to detain any offender whom they believed would be a risk to the public if released, in order to reassure the public that dangerous offenders would not cause society further harm (Pratt, 2008).

\section{New Zealand Preventive Detention Development}

Preventive detention was first legislated into New Zealand law in the 1954 Criminal Justice Act (Gavaghan, Snelling and McMillian, 2014; Meek, 1995), intended to be 'rarely' used on only the high recidivist or sexual offenders against children. Furthermore, and offender needed to be over the age of 25 and needed to have at least one prior similar conviction (Gavaghan et al., 2014). The provision was then abolished in the 1967 amendment to the Act, except for offenders who committed sexual offences (Gavaghan et al., 2014). The reasons for this amendment, provided by the then Minister of Justice, echoed the ethical concerns raised by criminal justice professionals such as the difficulty determining when release could be justified. Hence it was considered the best solution at the time to not impose 
indeterminate sentences at all (Gavaghan et al., 2014). As stated in Chapter One, the Report of the Penal Policy Review Committee (1981) then recommended the abolition of preventive detention. Their reasoning was that preventive detention was a redundant provision as it was rarely used. ${ }^{7}$ Further, concerns were raised during their review as to the arbitrary nature of indeterminate sentences.

However, although most of the Committee's recommendations were incorporated in the Criminal Justice Act 1985, preventive detention remained as a sentencing option in spite of the evidence presented by the Committee (Penal Policy Review Committee 1981; Meek, 1995). Indeed, this legislation can be said to be the start of its revival, even though restrictions on its use, such as a minimum age for the offender of 25 years and a requirement for at least two prior sexual offence convictions remained in the Act (Criminal Justice Act 1985). The Government indicated that the parameters were kept as a means to ensure the sentence was rarely used and only in extraordinary circumstances. The reasoning (as provided in the Justice Departmental report) was that if preventive detention was rarely used then there was no harm in keeping it as a sentence (Meek, 1995).

Meek (1995) pointed out that another reason for not abolishing preventive detention could be explained by a Commission of Inquiry (1983) which had published a report into the release of recidivist lan Donaldson (Meek, 1995). The report investigated Donaldson's release from a psychiatric hospital, arrest and release on bail, up until his suicide two weeks post-release. Donaldson left a note confessing serious sexual offences he had committed during the past year. However, Donaldson was granted bail because there were no court appearances listed on his criminal record, as he had been inside a psychiatric unit (Commission of Inquiry, 1983). From its findings, the Commission of Inquiry concluded that Donaldson would have been a prime candidate for preventive detention, as he was

\footnotetext{
${ }^{7}$ The Committee found the provision had only being imposed once between 1978 and 1981, and that one sentence was quashed on appeal by the Court of Appeal.
} 
part of a minority of relevant offenders who are not considered legally insane. This report was used to caution against abolishing the provision (Meek, 1995; Commission of Inquiry, 1983). However, the Commission of Inquiry also noted that it was against principles of punishment to detain offenders for future potentially harmful behaviours (Commission of Inquiry, 1983).

The findings of the Commission of Inquiry also indicate reasons for the moderate changes that were made to the Bill, which had originally been introduced by the Third National Government. The Fourth Labour Government, elected in 1984, was keen to demonstrate that, while it was strong on civil liberties, it was not going to be a hostage to the 'law and order' demands of the opposition National Party by abolishing preventive detention. But at the same time, it was not prepared to remove all ethical constraints on this sentence.

One of the modest changes in the 1985 Act was to give authority to the Parole Board, rather than the Minister of Justice to release prisoners serving sentences of life or preventive detention (Meek, 1995). The Government had shown strong confidence in the Parole Board to regulate imprisonment as the Board would consist of criminal justice professionals and would be removed from a political agenda (Hansard, 1984). The National Party opposition strongly opposed passing the enactment (Hansard, 1984). The Government argued that the release of offenders on parole was a decision that should be made by "experienced people on the basis of the best possible information" rather than on a political whim (Hansard, $1984 \mathrm{p}$ 2713). By vesting this authority in the professionals on the Parole Board, they argued that the severity of the sentence would be reduced (Hansard, 1984). In addition, the power to recall paroled offenders to prison was also removed from the Minister for Justice and instead vested in the High Court (Hurd, 2008; Meek, 1995). Once again, the Government argued that this was better suited outside of the political arena and made by an experienced practitioner (Brown and Young, 2000). Therefore, any recall decisions were to be made by a 
High Court Judge, after hearing evidence presented by Counsel (Hansard, 1984). This appears to be the compromise position reached with regard to accepting the Committee's recommendations to abolish preventive detention.

1987: Amendment to preventive detention widening the scope for sentence.

However, the intention for preventive detention to remain a rarely used sentence did not last long. Only two years after the 1985 Criminal Justice Act overhaul, the government amended the preventive detention provision, widening the scope of the sentence.

From 1986, there was greater public concern about increasing violent crime in New Zealand (Meek, 1995; Roper Report, 1987). In addition, there were structural changes stemming from radical social and economic reform initiated by the Fourth Labour Government, and significant upheaval as a result of the stock market crash in 1987, and which would ultimately lead to the emergence of penal populism (Pratt, 2007). There was an increase in unemployment, which combined with reduced state welfare and the loss of financial investments to create increased anxiety amongst New Zealanders. One of the repercussions of this anxiety and economic struggle was a rise in crime, and an associated increase in media attention (Pratt and Treacher, 1988; Pratt, 1995). This set the platform for law and order in New Zealand society to be one of the prominent features of the 1987 election campaign (Pratt and Treacher, 1988). As a consequence, there was a significant shift in the legitimacy of preventive detention seen with the 1987 Criminal Justice Act amendment.

Two crime incidents in 1987 were particularly influential in changes to preventive detention sentencing law. The first was the abduction of a six year old girl on her way to school. Five days after the girl was abducted, Peter Joseph Holdem was charged with her murder. This case received intense media attention because Holdem had a criminal record for repeat sexual offences on young girls. Holdem 
was sentenced to preventive detention, as he met the requirements for the sentence. The second case was that of John Douglas Bennett. Bennett kidnapped at knife point, assaulted and murdered a woman five weeks after his release from prison for abduction and attempted rape. This case in particular received wide media coverage, including a 'Closeup' television special titled 'Just Another Victim'.

Meek (1995) argued that the title to this television special had a double meaning: first, the last victim of Bennett's had been one of many; and secondly, the criminal justice system was indifferent to victims of crime. Although Bennett was sentenced to 10 years imprisonment for his crimes, the Judge noted that preventive detention would have been appropriate but, as Bennett was aged 24 at the time, he did not meet the age eligibility requirement for the sentence.

Two weeks after Bennett was sentenced the Minister for Justice announced that the Government would introduce a range of legislative amendments directed at violent offenders. However, when these changes were announced, the Minister stated that the amendments were based on the release of a study which analysed rape convictions in New Zealand from 1966 to 1985 (Meek, 1995) rather than public outcry that had arisen from the increased media crime reporting. It seemed as though the Government was insisting that its penal policy should be based on research rather than representations of 'public opinion'. The study surmised a link between violent crime and rape, and that the majority of violent offences were committed by those under 25 (Meek, 1995).

The Government reacted to the increased media attention given to crime by taking a strong stance against violent crime in particular (Pratt and Treacher, 1988). In 1987, a Committee of Inquiry into Violence (the Inquiry) was commissioned to determine what could be done to reduce violent crime in New Zealand. Based on public submissions, the Inquiry found that there was widespread concern and preoccupation with violence and violent crime. The concerns reflected the level of 
violent crime which was portrayed in the media, such as murder, rape and gangs. Thus, part of recommendations from the Inquiry included stricter prison and parole conditions for violent offenders. The Inquiry also found public concerns with violent television programmes and the influence such programmes were having on viewers. However, in response to this Inquiry, the Government did little to address the wider findings of the report but progressed the recommendations on toughening criminal justice provisions.

There were three changes made to the preventive detention provisions in the Criminal Justice Act in 1987 and 1988 (Brown and Young, 2000; Meek, 1995). First, the age of eligibility for the sentence was reduced from 25 years to 21 years. This was attributed to the rape research cited by the Minister of Justice, and significantly widened the scope of eligible offenders for the sentence. Secondly, the original list of qualifying offences that had consisted only of sexual offences was extended to now include a range of serious violent offences, thus widening the scope of qualifying offences for the sentence. The following year, a further amendment was made, extending the minimum non-parole period from seven to 10 years. In these ways, the reach of preventive detention was considerably extended, as was the length of prison time that would be served by preventive detainees.

The 1988 amendment ensured that offenders would remain incarcerated longer, purely on the basis of a predicted likelihood they would commit another serious crime in the future. These amendments essentially reversed the changes that had been implemented in the 1985 Criminal Justice Act amendment to reduce the arbitrary nature of the sentence. The ethical constraints that had been in place in legislation had now been overruled by an increase in the scope of preventive detention to appeal to the popular vote, one of the key pillars of penal populism (Pratt, 2007). 
Meek's (1995) analysis finds that after the 1987 amendments the Courts began to use preventive detention more regularly. Between 1987 and 199348 offenders had been sentenced to preventive detention, compared to 28 from 1968 to 1987 (Meek, 1995). Sentencing reports indicate that, not only were High Court judges more inclined to sentence offenders to preventive detention, but the Court of Appeal was also more reluctant to overturn preventive detention sentences (Meek, 1995). The amended preventive detention provision, along with the public's perceived fear of increasing crime, encouraged the judiciary to impose the sentence more frequently than it had done in the past (Brown and Young, 2000; Meek, 1995). Although the Judiciary would have been reluctant to impose preventive detention because of the ethical dilemmas and its lack of theoretical grounding in the penal profession, they were also reluctant to go against Parliament's legislated intention (McSherry, 2013).

\section{Human rights legislation}

Ironically, the expansion of preventive sentencing from 1987 coincided with a more prevalent human rights movement in New Zealand. Around the time that more punitive penal provisions were gaining popularity, New Zealand ratified the International Covenant on Civil and Political Rights (ICCPR) and enacted the Bill of Rights Act in 1990 in an attempt to take a 'rights based' approach to New Zealand law. On 28 December 1978, New Zealand ratified the ICCPR, agreeing to guarantee citizens a range of rights and freedoms, including prohibitions on arbitrary arrest and detention, and other relevant safeguards for the criminal justice system. However without introducing relevant domestic legislation, the ICCPR had no status within New Zealand.

In 1985 the Government released a white paper entitled 'A Bill of Rights for New Zealand', proposing a supreme law bill of rights which would allow the Courts to strike down inconsistent legislation. This proposal was controversial with the 
general public, leading to a significantly weaker Bill of Rights Act when it was introduced in 1990. The Bill of Rights Act 1990 gave civil rights protections to all New Zealanders. However, parliamentary supremacy was maintained so that inconsistencies with rights can be justified under section 5 of the Act. Further, while the Attorney-General must alert Parliament to the inconsistency of proposed legislation with the Act, there is nothing preventing Parliament from enacting inconsistent legislation. Although the judiciary are able to declare that legislation is inconsistent with the Act, this declaration places no obligations on Government to change the legislation.

In New Zealand, this human rights legislation has proved to be no impediment to the development of more punitive sentencing provisions with no consideration given to human rights or other ethical considerations. It is also evident that limits to rights and freedoms prescribed in the Bill of Rights Act can become easy to justify under section 5 of the Act (Butler, 2002) thus rendering useless any protections which may have been used against punitive sentencing provisions.

The lack of robust protection of rights under the Act allowed the continuation and expansion of preventive detention provisions in New Zealand without any consideration of a principled and ethical approach to preventive sentencing (cf Floud and Young, 1981). This is because the New Zealand Bill of Rights Act was to be used as a tool only when Judges were required to undertake a statutory interpretation exercise in a particular case (Butler, 2002). If it was found that a legislative provision did breach a protected right, Judges did not have the power to strike down inconsistent legislation (as do Supreme Court Judges in the US, for example). Furthermore, section 5 of the Act can be used to argue that, in the case of preventive detention and other similar provisions, the limit on the right to liberty would be justified. 
The limited powers of the New Zealand judiciary can be seen in comparison to those of the judges who sit in the European Court of Human Rights (ECHR). The ECHR is an independent court which hears complaints brought by an individual, or group of individuals, against the State. The ECHR has always held that under the European Convention on Human Rights that it has no jurisdiction to annul domestic law or administrative practices that are violating the Convention (Council of Europe, N.D.). However, under Article 46 of the Convention, state parties have undertaken to abide by the Court's final decision, therefore making the European Court's declaratory powers binding. Furthermore, in a distinct difference to New Zealand, the Committee of Ministers of the Council of Europe are charged with supervising the execution of the ECHR's judgements (Council of Europe, N.D.). This ensures that declarations made by the ECHR are followed through by the relevant country, whether through changes to its national law to comply with the convention rights, or through individual measures to remedy rights violations (Council of Europe, N.D.). It is this process of declaration and follow-through that ensures that human rights are protected in Europe. This form of follow-through process is something that New Zealand is lacking, leading to a lack of clear checks and balances on public protection sentencing (Butler, 2006).

A New Zealand case which highlights this contrast with the ECHR is that of Taunoa $v$ Attorney-General. ${ }^{8}$ Taunoa was a case in which prisoners who been held in de facto 'super-max' prison conditions and who had successfully argued breaches of section 23(5) of the Bill of Rights Act (everyone deprived of liberty shall be treated with humanity and with respect for the inherent dignity of that person), received significant monetary compensation for their rights infringements. This created a public outcry, which the Fifth Labour Government responded to by enacting the Prisoners and Victims' Claims Act (2005). The purpose of the Act was for victims to 'share' any monetary compensation awarded to prisoners if they had been

\footnotetext{
${ }^{8}$ Taunoa v Attorney-General [2007] NZSC [70]
} 
successful in a Bill of Rights Act claim. Instead of recognising the Court's analysis and findings to prevent future rights infringements, the enactment of the Prisoners and Victims' Claims Act overrode the declaration made by the Court that New Zealand prisoners could have claim under the Bill of Rights Act.

The response of the public and the Government to this case signifies a binary approach to human rights in New Zealand. While the validity of human rights is widely acknowledged, these rights are not believed to extend to those who commit crime, especially those who are imprisoned. This creates an environment where the violation of offenders' rights is applauded rather than condemned, encouraging harsher legislation, including the expansion of preventive detention. The lack of robust judicial oversight of, and supreme law status for, the Bill of Rights Act has allowed successive governments to continue these rights infringements without consequence.

1999 referendum and Sentencing Act 2002.

The next legislative turn for preventive detention in New Zealand was seen in the overhaul of criminal justice legislation in 2002. There had been, once again, increased public concern and fear about the perceived ever-increasing crime rate, combined with the upcoming 2002 general election (Roberts, 2003). However, the trigger for the legislative changes is generally acknowledged to be the 1999 Citizens Initiated Referendum (Hall and O'Driscoll, 2002; Roberts, 2003). This referendum proposed the controversial question:

\footnotetext{
"should there be a reform of our justice system placing greater emphasis on the needs of victims, providing restitution and compensation for them and imposing minimum sentences and hard labour for all serious offenders?"
}

The overwhelming response from the public was a 92\% vote "yes" (Roberts, 2003). 
Citizens Initiated Referenda were introduced by the National Government in 1993, under the Citizens Initiated Referenda Act 1993, allowing referenda to be triggered by a petition signed by at least $10 \%$ of the voting public (Roberts, 2016). The Government is unable to rewrite the question posed by the petition, but is not bound by the results of the referendum. Because of this, the National Government was committed to a referendum question in 1999 which asked multiple questions, with a simple yes or no response. Consequently, the incoming Labour Government did not institute all aspects of the referendum, such as "hard labour for all serious offenders", which has been argued by some (for example, Don Brash, then Leader of the National Party, in his address to the Sensible Sentencing Trust $^{9}$ in 2004) as ignoring the overwhelming will of the New Zealand public (Roberts, 2003).

Overall, the referendum was interpreted as indicating public concerns around the sentencing of serious violent offenders and widespread public agreement regarding the need for greater protection from dangerous offenders (Hall and O'Driscoll, 2002). This placed crime and justice on a central platform for the 2002 election campaign, with the ensuing Labour Government introducing the Sentencing Act, Parole Act and Victims' Rights Act in the lead up to it (Roberts, 2003).

The Sentencing Act 2002 sets out the purposes and principles of sentencing (at sections 7 and 8 of the Act, respectively). These reflect the ideals for sentencing and imprisonment that had been in existence in New Zealand law and policy since the 1980s, such as proportionality, rehabilitation and consistency in sentencing practices (Roberts, 2003). However, Roberts (2003) highlights that in the preamble to the Bill which led to the Act Parliament specifically addressed public concerns that had resulted from the 1999 referendum in an attempt to appear "tough on crime".

\footnotetext{
${ }^{9}$ The Sensible Sentencing Trust (formed in 2001) is a lobby group representing victims' rights and advocating for tougher sentencing and a more punitive justice system.
} 
Additionally, the provisions relating to dangerous and serious offenders were amended to ensure that those considered a danger to society would now be more likely to be detained indefinitely. The provisions for preventive detention are set out at sections $87-90$ of the 2002 Act. Its scope was widened once again. The age of eligibility for the imposition of the sentence was reduced once again from 21 years to 18 years, effectively removing the age restrictions from adult offenders. The range of qualifying offences was further increased, these are listed at section 87(5) of the Act, and include a range of sexual offences and serious violent offences.

The most pressing and significant change in the Act is the removal of the requirement for previous convictions before an offender can be sentenced to preventive detention. With the emergence of actuarial risk assessments in New Zealand in the mid-1990s (Gavaghan et al., 2014; Bakker, O'Malley and Riley, 1999), an offender only needs to be assessed for risk of potential future harm. Once this statistical analysis is complete, and a Judge is satisfied with the results, an offender is eligible to be sentenced to preventive detention. For the first time, there was no link between detention and recidivism.

A further change to preventive detention in the Act was the reduction of the minimum non-parole period, from 10 years to 5 years. Hall on Sentencing summarises that, due to the reduction in the minimum non-parole period preventive detention had very clearly moved on from being a sentence of last resort. The lower minimum non-parole period serves the purpose of making preventive detention a 'user-friendly' and more flexible sentence. This was so judges would not hesitate to impose preventive detention if the qualifying provisions were met (Hall and O'Driscoll, 2002).

The enactment of the Parole Act 2002 saw parole eligibility become more restricted than it had been under the Criminal Justice Act 1985, and its subsequent 
amendments (Hall and O'Driscoll, 2002). Under this Act it can be inferred that an offender who is deemed to be dangerous should remain in prison indefinitely. At section 6(4) of the Parole Act it is legislated: "an offender on parole for an indeterminate sentence is on recall for life". This is in comparison to finite sentences where offenders on parole are only eligible for recall until the end of their statutory release date. Furthermore, the power to make a decision to recall an offender shifted from the High Court to the Parole Board, indicating yet another barrier against arbitrary decision-making was removed by removing the independent role of a High Court judge to make the determination about a preventive detainee. The specific consequences of this are discussed further in Chapter 5 of this thesis. Finally, section 7(1) of the Parole Act provides that "the paramount consideration for the Board in every case is the safety of the community" (emphasis added), thus indicating the important role of public consideration in an offenders punishment decisions.

The enactment of the Sentencing Act and Parole Act in 2002 significantly broadened the scope for preventive detention. There was no longer an age limit for an offender to be sentenced to preventive detention; the scope of offences included a wider range of violent and sexual crimes; and parole conditions for offenders sentenced to preventive detention were tightened. Furthermore, dangerousness as a concept no longer included recidivism as one of its criteria. Since 2002 it has been determined by use of actuarial methods to predict the future likelihood of committing a crime. The legislative changes from 1987 through to 2002 abandoned any previous ethical concerns about the use of preventive detention and were contrary to the introduction of human rights legislation in the early 1990s. These changes, rather than being grounded in evidence, were enacted for political reasons to address the fear of the wider New Zealand public around dangerous and violent offending, as evidenced in the 1999 referendum result. 


\section{Chapter Three: The Rise and Development of Actuarial Risk for Dangerousness}

From the late $19^{\text {th }}$ century, dangerous offenders have been sentenced indeterminately based on a risk assessment indicating a risk of future possible offending (Hannah-Moffat, 2005). Originally, risk assessment was the role of psychology-professionals within the criminal justice system to assess and categorise offenders to determine the level of risk of harm they pose to society (Hannah-Moffat, 2005, 2013; Simon, 2005). Offender detention and rehabilitation programmes were then managed according to a high, medium or low risk rating (Hannah-Moffat, 2013; Harrison, 2011). However, the initial promise of prediction accuracy provided by clinical diagnosis had been largely discredited by the 1970s (Phelps, 2011; Simon, 2005; Steadman, 1980). Risk predictions, especially with regard to dangerous offenders and preventive detention, were debunked to the point that the American Psychological Association did not support psychologists as being skilled enough to 'predict' offender behaviour (Floud and Young, 1981).

However, the decline of the use of risk prediction in the criminal justice system was not long lived as from the 1980s risk and clinical professionals made a comeback in a new manner (Simon, 2005). The new risk assessment was now based on statistical calculations and therefore considered more reliable (Floud and Young, 1981; Simon, 2005). The report published by the Floud Committee in the UK (1981) was a significant review of the ethical dilemmas associated with indeterminate sentencing and dangerousness. It contributed to the revival and development of the 'new' risk assessment in the UK (Floud and Young, 1981, Bottoms and Brownsword, 1982). However, research clearly indicates the dilemmas associated with risk prediction remained through the revival of risk. These are even more present today as the breadth and scope of indeterminate 
sentencing and supervision programmes continue to grow (Hannah-Moffat, 2013; McSherry, 2013).

There has been considerable enthusiasm from criminal justice professionals for the new risk assessment in criminal justice (Hannah-Moffat, 2013; McSherry, 2013), as it is portrayed as an objective and reliable science and a means to remove inconsistency by removing judicial discretion (Hannah-Moffat, 2013; McSherry, 2013). However, there are concerns that reliance on statically based risk assessments removes judicial analysis which takes into consideration all of the principles, such as retribution and rehabilitation, that sentencing laws are built on (Hannah-Moffat, 2013). There also continue to be ethical concerns that are raised by penal experts (McSherry, 2014). Some of these concerns have remained since the initial beginnings of risk resurgence in the 1980s (Floud and Young, 1981; Simon, 2005). The main issue of detaining an offender for a future crime continues on the basis of a utilitarian theory of punishment (the elimination of a possible risk is to the advantage of the whole community), even if the method to determine risk has improved (Hannah-Moffat, 2013). Professor Norval Morris (1974, cited in Floud and Young 1981, p. 21) summed up the ethical dilemma associated with dangerousness, risk and preventive sentencing as:

"since we cannot make reliable predictions of dangerous behaviour, considerations of justice forbid us to confine people against their wishes in the name of public safety for longer periods than we can justify on other grounds".

This chapter discusses the revival and development of risk assessment in modern society, and the continuing dilemmas associated with punishment based on a predicted future harm. It will assess the ethical issues associated with risk prediction for the purposes of confining dangerous offenders and looks into 
whether modern society has ethically justifiable measures to continue using preventive detention as a sentence.

\section{The beginnings of the new risk assessment}

In 1976, the Howard League for Penal Reform ${ }^{10}$ convened a working party (Chaired by Jean Floud) to review and report on the law and practice regarding dangerous offenders in the UK. Following the US Supreme Court ruling of Baxstrom v Herold, in 1966 there had been much controversy around dangerousness in the US which sparked a review and reform of penal policy (Floud and Young, 1981; Phelps, 2011) with regard to dangerous offenders. In response to this, the working party was established to determine the principles which would limit and govern protective sentencing practises. The findings and recommendations of the Floud committee went on to establish the foundations for risk assessment in the UK criminal justice system. The report published by the Floud committee in 1981 (herein referred to as the 'Floud report') began with a broad discussion about the US context regarding dangerousness and risk that they were working in as well as the definitions and parameters for 'dangerous offenders' for the purposes of the report. The authors noted that the Floud report focused on those offenders who are deemed dangerous but are not 'mentally abnormal'.

The Floud report acknowledged that defining dangerousness, for legal purposes, is very difficult as both harmful behaviour and the risk associated with it are social constructs. In regard to punishment and sentencing, dangerous offenders fit into neither the 'mad nor bad category', where offenders do not meet the legal requirements for insanity and neither do they necessarily meet the requirements for a particular offence. For example, an offender could be referred to as a 'sexual offender' without the offence they are being sentenced for being sexual in nature

\footnotetext{
${ }^{10}$ The Howard League for Penal Reform is one of the oldest penal reform charities in the UK. It was established in 1866 and named after John Howard one of UK's early prison reformers.
} 
(Kozel et al., 1972 cited by Floud and Young 1981). Dangerousness is a spectrum, for which the requisite offender needs constant psychiatric assessment. There is no single test, as it is not a simple binary of an offender being either 'dangerous' or 'safe'.

However, by the late 1970s, it had become widely accepted across the US and UK that repeat violent offending was a key indicator of dangerousness, although this did not assist in forming a clear legal definition for the purposes of detaining or supervising an offender to prevent future harm (Floud and Young, 1981). The lack of legal conceptualisation of dangerousness was not helped by the use of clinical risk prediction which had become the standard mechanism for determining whether or not an offender met the dangerousness criteria. Clinical risk assessment was now essentially used as a narrative support of the statistical predictions that were calculated for a particular offender (Floud and Young, 1981).

Risk assessment has been described as a "predictive judgment" and not just a prediction (Floud and Young, 1981). This is on the basis that there is both evaluation and prediction involved, where the offender's character is evaluated, which involves assessing a disposition to behave in a certain way or commit a certain type of crime (Floud and Young, 1981). There also needs to be an estimate of the probability that in a foreseeable circumstance the offender will then behave in that way (Floud and Young, 1981). Judges essentially need to complete a predictive judgement and ask themselves the above questions as well as considering how likely it will be that the specific circumstance come up for the offence to occur in the foreseeable future (Floud and Young, 1981).

In the context of this 'predictive judgement', the Floud report discussed the merits of actuarial methods, the adaptation of which had by then revived preventive sentencing in the US (Floud and Young, 1981; Phelps, 2011). The report found that actuarial methods were preferred because of their statistical nature and hence 
ability to categorise offenders and making the process consistent and 'exact'". Actuarial assessments provided an objective and scientific means to predict risk of offenders, in contrast to the overly subjective methods of clinical prediction.

US studies during the early 1970s, which followed the Baxstrom case (Monahan et al., 1981; Cocozza and Steadman, 1976, 1980; Steadman, 1980), found that risk predictions had a 50/50 chance prediction. Some had come to the view that this was the best that could be done with the information and tools and techniques available at the time. Taking into account the nature of the crimes committed by dangerous offenders it was considered better to be cautious and detain someone who had a prior history of offending and other indicators of dangerousness, such as no family or community support, than to not protect public from this type of offender (Floud and Young, 1981). Professionals in the field, including the American Psychological Association, condemned psychologists' ability to predict risk of offenders. One of the most widely cited studies of this era is one of the Baxstrom patient follow up studies completed by Cocozza and Steadman (1976). The Floud report notes the significance of the claims of this paper, as Cocozza and Steadman were able to look into the assessment reports of the Baxstrom patients and found that there was no significant difference between those who were found dangerous and those who were found safe. Thus, the Floud report (1981, p30) concluded that this study showed "clear and convincing evidence only of bad practice, not of the state of the art of assessing dangerousness". It is surprising that from assertions such as this and the finding of the Supreme Court, that risk and preventive sentencing found a way back into the justice system at all. In addition, risk assessment has continued to develop and be increasingly used by the justice system since the 1990s (Simon, 2005).

The Floud report states the Committee's view that as long as predictive judgments are a part of the administration of justice, then there is a moral obligation to continue to try and improve the quality and practise of risk assessments to reduce 
unnecessary detention. Hence, it was important to consider the merits and disadvantages of the new methods of risk assessment that were emerging in the US criminal justice system. The new risk assessments were developed from tools that were used to calculate risk for insurance premiums as well as use in University admission in the US (Simon, 2005). Although the new actuarial methods were designed to be objective and standardised in theory, in practise the individual characteristics of offenders do need to be taken into account in order to make the risk prediction. It would seem that this would explain why the 'new' risk assessment did need some form of clinical assessment to supplement statistical probabilities.

It is important to note a significant difference between the US and English justice systems. In the US, the role of psychologists was prominent in the criminal justice system. Lawyers routinely called on psychologists as witnesses in order to taint the viability of character. In England, in contrast, risk assessments were completed more behind the scenes, and more commonly by the Parole Board which had a role as a review authority and relied on a range of sources from a number of professionals.

It was because of this difference in practice between the US and UK jurisdictions that it made sense for critics in the US (at the time) to state psychologists were no better than laymen to make decisions on dangerousness and as a result called for strict rules around psychological evidence (Floud and Young, 1981). The rules and structure around psychological evidence was on the basis that Courts should not presume expertise as clinical judgments were no better than opinion or interpretation (Floud and Young, 1981). Other arguments in the US that were considered included the role of the public (through a jury) in determining if an offender should be subject to preventive sentencing on the basis of 'reasonable fear' or 'justifiable public alarm' (Floud and Young, 1981). 
The Floud committee, on the other hand, was of the view that when considering whether or not to impose a preventive sentence a judge should review the evidence and give a reasoned and as specific as possible statement of the risk posed by the offender, as a judge was the most experienced and qualified to make that decision (Floud and Young, 1981).

Although the Floud report began with a strong stance, setting up the context to their inquiry and recommendations as one of not supporting risk prediction in the criminal justice system, once the report delved into its analysis and recommendations there are some contradictions between standpoints that are taken (Bottoms and Brownsword, 1982). For example, although there were strong statements made about the lack of confidence and theory behind risk in the criminal justice system, the recommendation made is for a 'just re-distribution' of risk for it to be justifiably used in the justice system. This has been critiqued as a non-ethical foundation (Bottoms and Brownsword, 1982). An ethical foundation begins with the assumption that State has a duty to treat all citizens with equal concern and respect and every citizen has a rights claim against the state (Bottoms and Brownsword, 1982). The importance of a right is that it should not be set it aside for the sake of political expediency or public interest, as seems to be the basis of the just-distribution of rights arguments made by the Floud Committee. But rights are fundamental in a democratic society (Bottoms and Brownsword, 1982). Alternatively, it could be seen as a practical recommendation, one of least possible interference to the offender, at a time when there seemed to be a strong political movement for preventive sentencing and the use of risk assessment across Western society (Phelps, 2011; Simon, 2005). This was happening at the same time that there was a strong movement against preventive sentencing from academics and criminal justice experts (Bottoms and Brownsword, 1982). Either way, the report indicated the lack of consensus regarding risk and criminal justice system. In essence, there were "inescapable uncertainties and dilemmas" that the 
State and society must accept when protective sentencing is considered a need in modern society (Floud and Young, 1981).

The central practical question for the Floud committee was whether, as a matter of penal policy, there should be any special custodial sentence for the purpose of providing greater protection from one type of offender. The answer, from a number of criminologists and penal policy experts at the time, was a resounding 'no' due to the fundamental objections - from both the legal and academic community - to detaining people for longer than needed in the name of public protection. This was especially so when the offender in question is of sound mind and capable of taking responsibility for their actions (Floud and Young, 1981).

Von Hirsch (1972) argues that a basic rule of criminal justice in a free society is that an adult of full mental capability should not be deprived of their liberty except as punishment for a crime for which they had been convicted. Public protection in the criminal justice system is only for the purpose of punishing an offender justly and for past conduct - predictive judgements for future conduct should not be a part of the system. The dilemmas regarding its place in the criminal justice system are summarised by von Hirsch (1972 cited in Floud and Young, 1981, p39) as follows:

"...No one, not even the offender himself can be certain that he will or will not reoffend ... infringe his right to self-determination and risk the injustice of punishing him in advance for an offence which he may not commit".

Furthermore, by imprisoning offenders based purely on an arbitrary category, the justice system consequently generates second class citizens. This concern expressed by the committee in its report has become a regular feature of contemporary justice and penal systems, as will be discussed further in the next chapter. 
Walker (1978, cited in Floud and Young 1981) argues that protecting the public should be taken into account at sentencing, as people are prevented from activities that could harm society in a number of other instances. For example, epileptics are stopped from driving for the potential harm they could cause; or people with a contagious disease (such as the plague or yellow fever) ${ }^{11}$ are quarantined. This argument raises the question of whether there is an ethical distinction between protective sentencing and quarantine. The authors' note the important distinction is that dangerousness is not a medical disease, such as which those people who are quarantined are contaminated with. This of course, comes back to the point that dangerousness is a social construct rather than a medically or legally defined term (Harrison 2011; McSherry, 2014). Furthermore, if dangerousness was to be considered a medical condition, the State would be punishing people for what they are rather than for any criminal offence (Floud and Young, 1981; Keyzer and McSherry, 2015; McSherry, 2014). A 'medical' consideration of dangerousness would therefore not resolve ethical issues associated with risk and dangerousness and it would result in the State being on a 'slippery slope' towards universal preventive confinement (Bottoms and Brownsword, 1982; Floud and Young, 1981). Furthermore, risk assessment is only confined to offenders as opposed to the general population. It is this intrinsic link to the criminal justice system that ultimately makes the penal provision one that is based on utilitarian theories of punishment, instead of the retributive theories that most penal law and policy is based on (Floud and Young, 1981).

Although the basis of utilitarian theories is empirical justification (Hannah-Moffat, 2013), which arguably the objective risk component to the sentence justifies, preventive sentencing requires a moral justification as well (Floud and Young, 1981). This justification becomes a moral choice between two risks - the balance between the risk of harm to potential victims compared to the risk of

\footnotetext{
${ }^{11}$ A full list of notifiable infectious diseases in New Zealand can be found at Schedule 1 of the Health Act 1956
} 
unnecessarily detaining offenders deemed to be dangerous. There is recognition that, despite the strong arguments against the use of risk assessment and preventive sentencing because of the ethical concerns raised, there continues to be a need for some form of detention for the small number of offenders who cause grave, irreparable harm to broader society (Floud and Young, 1981; Harrison, 2011). Thus, Floud and Young suggest there is a need to have a "just redistribution of risk in circumstances that do not permit of its being reduced" (Floud and Young, 1981 p49). The conflict amongst professionals is seen with this point. The argument made by the Floud report regarding the 'just redistribution' of risk appears contradictory to much of Von Hirsch's (1972) work, cited throughout the beginnings of the report.

Bottoms and Brownsword (1982) also critiqued the just re-distribution theory, on the basis that the committee was lacking in their findings and recommendations by not adopting a rights-based theory to risk and dangerousness. Bottoms and Brownsword's view was that the premise of grave harm that was used for the just re-distribution theory was essentially arguing that an offender should take on the risk of being unnecessarily detained for the sake of minimising some risk to the public. Bottoms and Brownsword (1982) were of the view that the Floud committee had a very narrow and limited perspective of how rights operate. There is an important principle which was missing from the Floud committee's just re-distribution theory: that is, an acknowledged right can only be overridden by giving priority to a competing right. Therefore, "a right cannot be put to one side simply on the grounds of convenience, expediency, or general utility" (Bottoms and Brownsword, $1982 \mathrm{p} 235)$. Due to the nature of risk prediction, with it having been found in many instances to at best have fifty percent accuracy, it is only in very exceptional circumstances that breaching offenders' rights' will be justified (Bottoms and Brownsword, 1982). 
However, in the consideration of what the Floud report referred to as 'practical ethics' of preventive detention, the claim to balance rights is grounded on the basis that with certain crimes, such as sexual offences, considered horrific and reprehensible, it is thought inconceivable for there to be even a small chance the offender would repeat the crime (Floud and Young, 1981). Therefore, there needs to be a sentence that can be imposed in such circumstances, stressing that it should be rarely imposed and only for the worst crimes. However, Bottoms and Brownsword (1982) found that the Floud report had underestimated the number of times the sentence would be imposed, thus further weakening their practical ethics grounds for the recommendations made.

Furthermore, the report recommended that instead of restricting the sentence to particular types of offences, it should, instead, be dependent on a particular level of harm. In making this claim, the committee did not consider that this would essentially be building another layer of prediction into the justice system, as it would essentially require a discretionary decision to determine what would meet a particular level of harm. There would also be a lack of consistency as discretionary decisions can vary depending on the judge making the determination. This then seems to be contradicted by the recommendation that only certain higher courts should have the authority to impose preventive sentences, as in most jurisdictions serious offences are dealt with by higher courts.

These contradictory recommendations, with a lack of consideration for how they might operate in practice, seem to flow through to all of the recommendations that were made in the Floud report. It included the option for finite rather than indeterminate sentencing, which was then considered not to be a viable option as it would not convey the level of protection that society perceives it needs. The concept of non-custodial sentences was also recommended but then revoked as it would not be practical to impose and monitor. Bottoms and Brownsword (1982) pointed out that the recommendations in the Floud report were structured in a 
way that they could be interpreted more broadly than the committee intended them to be, and consequently there was potential for far reaching policy to be developed from it. There was much that was left open to interpretation and much detail lacking as a result of the lack of cohesion between a number of arguments. However, although there is criticism for the recommendations posed by the Floud committee, it can be seen that the committee did fulfil its aim to consider 'practical ethics' and offer practical solutions for what was a contested area.

\section{The new and improved risk assessment and its continuing dilemmas}

Since the Floud committee review and debate on the role of risk assessment in the justice system, the popularity of risk assessment has steadily grown along with developments in risk tools used for different types of offending. Nonetheless, one theme which remains in present day risk literature is the continuing ethical dilemmas associated with risk prediction (Hannah-Moffat, 2013; McSherry, 2013). Risk tools are predominately used to predict future offending for the purposes of depriving an offender, or in some case a suspect, ${ }^{12}$ of both liberty and autonomy on the premise that the State does not trust them to be an autonomous functioning member of society (Hannah-Moffat, 2013; Magee, 2013; McSherry, 2014).

Although the concerns remain around the principle notion that an offender is being punished, in an extremely punitive and depriving manner, for predicted future offending (McSherry, 2013), there have been developments in the arguments for the unethical nature of risk assessment tools in and of themselves (Magee, 2013). From its beginnings in the 1980s, risk assessment made a complete return to the justice system in the 1990s, in conjunction with a political demand for methods to prevent violence (Simon, 2005). The new statistically based risk

\footnotetext{
${ }^{12}$ In Scotland there has been a development of an anti-social behaviour order which can see delinquent youth monitored or detained based on a potential risk of harm they pose to a community, without actually having committed any criminal offending: see McSherry (2014)
} 
assessments were even endorsed by critics of the original clinical assessments, such as Henry Steadman (of the post Baxstrom decision research). It was in the late 1980s that there was an introduction of dynamic features (such as family support and employment prospects) into risk tools (Hannah-Moffat, 2013). Andrew's (1989 cited in Hannah-Moffat, 2013) study, a pioneer of dynamic risk assessment, found that, in order for risk tools to improve accuracy, there needed to be consideration of both static and dynamic factors. The dynamic aspect of risk tools included the incorporation of other well-established clinical resources such as the Psychopathy Checklist (PCL) as well as the personal circumstances of an offender, to help inform the risk assessment (Hannah-Moffat, 2013; Simon, 2005). This would allow for broader consideration of circumstances for dangerous offenders, and it was hoped that it would result in fewer indeterminate sentences being imposed (Hannah-Moffat, 2013).

However, there is also an argument that making more rigorous and methodologically sound tools may be irrelevant due to the political need to imprison offenders who the public considers to be dangerous (Simon, 2005). There has been significant increase in the development of civil commitment legislation in order to succumb to increased pressure to, not only imprison dangerous offenders, but to keep them in prison for longer. As a consequence, the judiciary will also be guided by the public interest rather than robust statistical tools identifying how a risk can be manged by the correctional system as a whole (Simon, 2005).

This can be linked to the fact that risk assessment has increasingly become a function to manage and control dangerous offenders, through the use of imprisonment, rather than being used to determine treatment options to assist in reducing the risk an offender may pose (Hannah-Moffat, 2013). Essentially, risk assessment continues to be a prediction tool akin to clinical assessments as it is based on a 'group fit' framework, where an offender is matched as closely as 
possible to either a high, medium or low risk category and then sentenced on that basis (Hannah-Moffat, 2013). The new risk assessment is protected from the claims of being a 'less than chance' prediction due to its statistical and scientific basis (Hannah-Moffat, 2013; Simon, 2005). However, Hannah-Moffat (2013) argues that the knowledge on risk tools thus far does not allow for an absolute statement about offenders' recidivism, the timing of recidivism or how an offender will reoffend. For example, a risk tool cannot distinguish whether future offending will be violent or sexual in nature, or whether it will be a more minor breach a bail condition. It is for this reason that risk tools need to be used for a rehabilitative purpose rather than for the purposes of imposing an indefinite sentence or a supervision order (Hannah-Moffat, 2013).

\section{Actuarial risk tools in New Zealand}

The issues with risk assessment are as evident in New Zealand criminal justice as they have been in the US, Australia and the UK (Magee, 2013). The main risk tool that is utilised by the Department of Corrections is the Risk of re-Conviction X Risk of re-Imprisonment model (RoC*Rol), which was developed by Corrections psychologists in the 1990s, using the criminal histories of over 133,000 offenders (Gavaghan et al., 2014). RoC*Rol is used at sentencing and parole hearings, and for determining rehabilitative treatments for offenders (Magee, 2013). It was initially developed to prioritise treatment and prison rehabilitation programmes for inmates, as most risk tools are intended to be, but was then developed into a tool to predict the likelihood of reconviction of serious offences (Gavaghan et al., 2014).

The tool considers factors such as previous offending, length of sentence and seriousness of offending, which is then compared to an individual's data set to generate a numeric score of likelihood of future reconviction and re-imprisonment (Magee, 2013). Although a Corrections analysis has found the RoC*Rol to be 
'highly accurate' (Gavaghan et al., 2014) it is also limited in its ability to predict future criminal offending or take into account offenders' rehabilitation progress (Magee, 2013). The lack of ability to input important information, such as clinical progress and the age and health of an offender, has been heavily criticised by a number of penal experts (Hannah-Moffat, 2013; Magee, 2013; McSherry, 2013) as it is a significant factor in determining an offender's risk level (McSherry, 2014). This is concerning as there is a tendency for Courts to consider a risk assessment as a predictor of future offending, despite the tool's inability to assess this. The overuse and over-reliance on these tools contribute to increased numbers of preventive detention sentences, essentially amounting to arbitrary detention (Magee, 2013). There is not enough weight given to the fact that risk tools provide a probability of risk in the future, which should not go onto guarantee a prison sentence (Magee, 2013).

Furthermore, there are concerns with the inherent bias of risk tools, as they are generally developed from offenders with violent or sexual offending histories (Magee, 2013; McSherry, 2014). This not only creates a bias towards high assessment scores for the offender, but it also fails to consider the range of other offences, such as 'white collar' crime (Magee, 2013). This, of course, is an issue with the concept of dangerousness overall as there is no objective definition of what constitutes a 'dangerous' offender (Magee, 2013). However, the significance of these concerns with risk tools, including the RoC*Rol, is that the platform on which they are promoted creates an assumption that a preventive detention sentence is reasonable or justified (Magee, 2013). This then hides the dilemmas that have been discussed in this chapter. In New Zealand section 87(2)(c) of the Sentencing Act 2002 establishes a low threshold for determining preventive detention, as it uses the word 'likely' in the context of an offence happening (Magee, 2013), and enabling preventive detention to become a much more regular sentencing instrument. This is a broader term than 'grave harm' which was 
proposed by the Floud committee in 1981. Magee (2013) argues that the threshold to accept risk should be much higher, such as 'serious danger', in order to reduce the impact of overreliance on a potentially biased risk prediction.

These concerns have been reflected in the New Zealand Court of Appeal decision of $R v$ Peta. ${ }^{13}$ This was a case appealed by Peta, who had an Extended Supervision Order (ESO) ${ }^{14}$ imposed on him for 10 years. The ESO was not only based on an incorrect risk score but one which the risk assessment had been misinterpreted by the psychologist running the assessment (Gavaghan et al., 2014). This led to incorrect evidence presented to the Court, and the error was not established until the risk assessment was reviewed by a senior psychologist after the appeal had been filed (Gavaghan et al., 2014). At appeal, the psychologist for the appellant gave expert evidence that incorrect procedure and interpretation of result is potentially worse than not using risk tools at all, because risk assessments have 'scientific weight' behind them which then translates into strong, reliable evidence in Court. This case highlights the level of human error that can occur in risk assessments, similar to the over-cautious assessments of clinical assessments before the 1970s. Essentially, there is no way to reliably predict future harm and the results of such assertions can have far reaching consequences for the offender, who can ultimately be detained for life.

It is for the reasons discussed through this chapter, that a large body of academic opinion strongly argues that risk tools in the justice system should be used only for the purpose of determining the level of treatment or rehabilitation that an offenders needs in order to reduce their risk of reoffending (Hannah-Moffat, 2013; Magee, 2013; McSherry, 2014). It would be a more ethical option to focus on the issue of why some offenders are at risk of reoffending rather than how much of a risk an offender is to society (Magee, 2013). This would also be a more valuable

\footnotetext{
${ }^{13} R$ v Peta [2007] NZCA [67]

${ }^{14}$ This is discussed further in Chapter 4.
} 
use of resources while legitimately reducing risk to the public through a focus on altering harmful or abnormal behaviour (Hannah-Moffat, 2013). Magee (2013) believes that there will always be a dilemma with using risk assessments as there are two options: either the systems need to be improved in order to be robust and able to consider of all important dynamic factors which determine level of risk; or preventive detention needs to be abolished as a sentence. However, the first option is most likely unattainable, due to the changing concept of dangerousness which in turn will mean risk factors will keep changing and the second option is one which is likely to be politically unrealistic (Magee, 2013). Black (2011) argues that, when there is victim and offender, it is not about competing rights; instead, it is about balancing rights in a limited and justifiable manner. This would align with what is set out in the New Zealand Bill of Rights Act, therefore it should not be considered whether preventive detention sentences are justifiable, but whether or not the use and practice of imposing the sentence is defensible (Black, 2011).

McSherry (2014) provides a practical and valuable perspective on how risk assessment and preventive detention can be defensible. McSherry (2014) refers to this as the 'middle ground' ethical approach, which sits somewhere between always and never using risk assessment. McSherry (2014) proposes that sometimes using risk assessment can be justifiable if there are standards for the clinical professionals who complete risk assessments. These standards need to be similar to that of medical ethics standards, and could include standards requiring the psychologist to always work for the benefit of the offender. In this approach, the assumption should always be that there is some prospect of treatment or other benefit available for the offender (McSherry, 2014). There should also be a 'justice ethics' framework that risk assessors must work to, in which clinical professionals must attest to a true belief of the assessment and recommendation, whether or not it is an advantage or disadvantage to the offender (McSherry, 2014). In order to assist with the justice ethics framework and ethical standards, 
McSherry (2014) finds there should be an independent body, established under statute, to determine standards, issue guidance on risk practice, and accredit risk assessors. Finally, there would need to be some resources which provide rehabilitation and treatment programmes for offenders, rather than locking them away indefinitely, in order to target the causes and assist victims. There is certainly more development needed regarding risk assessment in New Zealand, before it can be considered ethically defensible. 


\section{Chapter Four: Detaining the Dangerous}

Chapter Two looked at the development of law and policy for the management of dangerous offenders in New Zealand from the 1980s through to present day. In particular, that chapter outlined how the concept of dangerousness changed over time, based on changing societal constructs and fears. This chapter will look at the means by which dangerous offenders are detained by the State. It will expand on some of the ethical arguments regarding risk raised in the Chapter Three. Despite concerns from professionals in the field about the unresolvable ethical dilemmas, mostly stemming from determining a sentence based on probability of risk of future offending, preventive detention has only expanded in scope. It has now moved into the civil law area. If dangerous offenders cannot be detained under a criminal sentence there are now civil law provisions available to authorities that then impose supervision orders on offenders for the purpose of public protection.

The first section of this chapter will discuss international trends in the management and control of dangerous offenders. The second section will address methods for management and control in New Zealand, and analyse whether there is any alternative to the use of imprisonment. The third section will address the importance of an external human rights body to monitor state imposed methods for detaining and managing dangerous offenders. The final section discusses New Zealand provisions for detaining the dangerous.

\section{International trends in dangerousness}

Since the original laws for indefinite sentencing were introduced, there have been significant developments in most Western societies for the management and control of dangerous offenders. McSherry (2014) provides a comprehensive comparative analysis of state control for 'dangerous offenders' imposed in the US, Australia and the UK. The findings show that the US and Australia have imposed 
punitive regimes for State control of dangerous offenders with greater ease than have England and Scotland.

A significant reason for this is the lack of independent control over legislative regimes and changes in the US and Australia. In these countries, law making power rests with the Government, and there is no imperative to comply with judicial direction opposing any law made. This is especially so in Australia, which is similar to New Zealand in that there is no external judicial body to provide critique or an independent view on a particular case. In the US, however, the Supreme Court is more powerful than comparable courts in New Zealand as it has the power to strike down legislation which it finds to be non-constitutional. It is, however, very reluctant to intervene in matters of local state penal administration (Simon, 2007). The Australian High Court also has the jurisdiction to strike down legislation which it deems to be unconstitutional (Fardon, 2004), in the case of Kable v Director of Public Prosecutions, ${ }^{15}$ where the New South Wales Parliament passed an Act to authorise the preventive detention of one individual, the High Court of Australia struck down the Act on the basis that it breached the fundamental doctrine of separation of powers. The High Court held that an Act enacted against a sole individual, instead of addressing a general social problem, where the Supreme Court was to determine the preventives sentence was essentially asking the Court to perform a political function. This function of performing a "non-judicial function" was in breach of the Constitution and hence the Act was considered invalid (Fardon, 2004; Kable 2013). However, despite the ability of the higher Courts to strike down unconstitutional legislation, detaining the dangerous in both the US and Australia continues to be achieved predominantly through legislative provisions which allow arbitrary imprisonment in the name of public protection. The penal regimes for detaining the dangerous in Australia and the US have increased in their punitive and arbitrary nature since the late 1970s (Phelps, 2011).

\footnotetext{
${ }^{15}$ Kable v Director of Public Prosecutions (NSW) [2013] HCA 26, (2013) 252 CLR 118.
} 
The lack of consideration for the ethical arguments that have been raised in regard to imprisonment of dangerous offenders, has seen the US and Australia develop civil commitment regimes to detain offenders after they have served a punitive term for a criminal offence.

There are six states in Australia, and 20 states in the US that allow for the postsentence detention of dangerous offenders (McSherry, 2013). This is a significantly different process to an indefinite sentence of imprisonment imposed by a judge, as is evident in many common law countries. The distinctly different nature has meant that post-sentence commitment orders have at times been referred to as 'double punishment' (McSherry, 2013) where an offender is serving two sentences for one crime because post-sentence detention allows the state to continue to imprison an offender, based on a perceived risk of re-offending, once a Court ordered prison sentence is completed. However, most of these claims are largely refuted on the basis that such orders are required for public protection (McSherry, 2013).

The US first enacted a form of civil commitment order in the 1930s, in the form of sexual psychopath laws (McSherry, 2013; Pratt, 1997). This legislated for the incarceration of offenders to provide treatment for their 'condition' which caused deviant behaviours, in lieu of a standard prison sentence. These laws were very broad and encompassed homosexual activity, transvestitism and sex crimes against children. By the 1960s the sexual psychopath laws had been repealed due to the heavy criticism for their lack of treatment programmes that were provided for these offenders. Furthermore, these measures were rarely used due to the severe encroachment on human rights and due process (Pratt, 1997).

However, the 1990s saw the introduction of new laws in the US which allowed for the incapacitation of 'sexually violent predators' through civil commitment orders. These laws provided that an offender deemed to have a mental abnormality 
(which could include paedophilia) and not in control of their harmful sexual behaviours, could have an involuntary civil commitment order imposed them after they have served a finite term of imprisonment (Vess, 2005). The aim of these laws was to 'cure' an offender of their sexually abnormality and therefore protect the public (Vess, 2005). Although there are criteria for when an offender can be detained under a civil commitment order, these are very broad with an emphasis on the protection of the public. Thus, there is little difference between a civil commitment order and a sentence of preventive detention, both serve to punitively detain dangerous offenders, just under different processes. In the US Supreme Court case of Kansas $v$ Hendricks ${ }^{16}$ the laws were upheld as constitutional on the basis that there is no breach of the prohibition on double jeopardy, because they do not establish criminal proceedings, this means involuntary confinement under the law would not constitute punishment (Vess, 2005). The Court even went a step further and held that the provisions would still not be unconstitutional even if there was no treatment provided to those offenders on which the order is imposed, as it is imposed for the purposes of confinement due to the detainees' "mental abnormality".

Australia enacted similar laws to allow for civil commitment orders for dangerous offenders. In Queensland, the enactment was the Dangerous Prisoners (Sexual Offenders) Act 2003 (McSherry, 2013). One difference to the US civil commitment laws is that Australian laws do not provide criteria for determining when an offender should be subject to a civil commitment order. However, McSherry (2014) argues that this difference between the US and Australia is insignificant due to the broad nature of the criteria established in US legislation. The purpose of the legislation in both the US and Australia is to provide the maximum public protection by keeping dangerous offenders detained after they have completed a punitive sentence.

\footnotetext{
${ }^{16}$ Kansas v. Hendricks 521 U.S. 346 (1997).
} 
The first offender subject to the Dangerous Prisoners (Sexual Offenders) Act 2003 in Queensland was Robert John Fardon. After receiving the indeterminate sentence for sex crimes, Fardon challenged the constitutional validity of his sentence on the basis that it authorised the Queensland Supreme Court to order the civil commitment of an individual without a fresh crime, trial or conviction and therefore amounted to double punishment. The basis for Fardon's challenge to the unconstitutional nature of the Dangerous Prisoners Act (2003) was the High Court's previous decision in the case of $\mathrm{Kable}^{17}$ (discussed above) where similar legislation was found to be unconstitutional by the Court. The distinct difference, which made Fardon's challenge fail, was that the 2003 Dangerous Prisoners Act was not directed at one particular individual but an Act of general application to those offenders who pose a risk of harm to the community. Hence the majority of the High Court did not uphold Fardon's claim. The High Court held that the law as drafted is directed at a class of criminals and not an individual and that it is a common law sentencing principle that the safety of the community is a relevant consideration. (Fardon, 2004; McSherry, 2014). The majority of the Court emphasised that it is the role of the Court, as set in the Constitution, to apply laws enacted by parliament and to critique the laws would then in itself become a breach of the Constitution. It was also considered that the argument made by Fardon regarding the lack of trial or conviction was not applicable to his civil commitment order as it was not subject to criminal procedure (McSherry, 2014). Fardon was essentially attempting to find redress at the High Court because the State level judicial procedure did not provide the path for this (judgement of Gleeson CJ, in Fardon). It was reiterated that Kable is a decision of very limited application due to the particular ad hominem nature of the law that was at issue in Kable. $^{18}$

\footnotetext{
${ }^{17}$ Kable v Director of Public Prosecutions (NSW) [2013] HCA 26.

${ }^{18} \mathrm{McHugh} J$ in Fardon v Attorney General for the State of Queensland [2004] HCA 46.
} 
The High Court also held that detention inside prison is not classed as punishment if it is ordered for non-punitive reasons. Essentially, the Australian High Court followed the reasoning of a previous case (Al Kateb $v$ Godwin, 2004, in which the High Court found that legislation to indeterminately detain a stateless person was not unconstitutional), to hold that under the Dangerous Prisoners (Sexual Offenders) Act 2003 detaining dangerous offenders under a civil commitment order was not punitive because the order was made on the basis of public protection, rather than punishing an offender for a crime.

It was only the one dissenting Judge (Justice Kirby) who expressed concern with the majority Court reasoning. Justice Kirby held the view that the liberty of individuals is the most important human right, and thus any deprivation of liberty must be seriously considered by the Court. Justice Kirby argued that calling the detention of an individual (in these circumstances) anything other than punitive or punishment (as did the majority of the Court, claiming that the sentence was administrative) removes an important constitutional protection of an independent judicial assessment to determine if the deprivation of liberty is lawful. Justice Kirby also went onto note that if the Act did in fact allow for a post sentence civil commitment order (as was claimed by the majority of the bench) then it would appear much different in practice. The detention would not be in a prison, but a separate facility designed to provide rehabilitative treatment to restore the post sentence offender to a state to then return to mainstream society, where the person's liberty would be protected by constitutional provisions. Justice Kirby's view was that in allowing for the law to be drafted and interpreted as it was by the majority of the Court, could mean a person could spend the remainder of their life inside prison because of a future predicted harm. This removes the fundamental principle in the Australian justice system (and other Western justice systems, such as in New Zealand, the UK and the US) of the presumption of innocence. 
This view provided by Justice Kirby highlights the importance of non-custodial options for preventive detainees. There needs to be (as seen in the German Criminal Code provisions considered in $M v$ Germany, discussed further below) a distinctive difference in not only how dangerous offenders are detained but where. It cannot be enough for there to be government policy which claims that rehabilitative treatment and counselling will be provided to high risk dangerous offenders, there needs to be a separate facility that provides for the needs of these offenders which their detention is premised on. This not only would help in providing the least intrusion on an offenders fundamental human rights, but it is also important for legislation to stand by the fundamental principles the justice system is built on, as noted by Justice Kirby, the presumption of innocence as well as the independent and impartial role of the judiciary. .

Similar to Australia, the US state legislatures have also been careful to not draft civil commitment laws in punitive terms, and to instead focus on the risk to the public and the need to provide protection against this. For example, when committing sexual violent predators, mental illness is not sufficient evidence. There must also be an element of dangerousness that stems from the mental abnormality which leads to serious difficulty in controlling behaviour (Vess, 2005). Therefore, law from these two countries indicates a prevailing belief that dangerous offenders can be detained in punitive conditions, as long as the reason for their detention is not for punitive reasons. This seems to create an unusual contradictory concept, whereby laws to detain dangerous offenders are upheld as constitutional by the highest court in both the US and Australia. McSherry (2014) points out that this constitutional compliance is generally achieved through judges applying a very broad interpretation to domestic law and with this broad interpretation and application approach, it can then become arguable that in some cases, the domestic law may not necessarily breach international human rights law. This of course is not assisted by the principle that international human rights 
law does not have jurisdiction in a case unless the country has incorporated the international law provision in question into domestic law.

In addition to civil detention legislation, the US introduced sex offender registration. This was in response to high profile cases of crimes against children at the time, the catalyst case for the law being the abduction of an 11 year old boy who was never found (McSherry, 2013). The purpose of the Jacob Wetterling Crimes against Children and Sexually Violent Offender Registration Act, passed in 1994, was to register dangerous offenders on a state system, to reduce risk and prevent reoffending, as well as to assist child protection authorities to know when a child could be in danger (McSherry, 2013). The law was initially established to ensure that any person who offended against a child, or committed any sexual or violent acts against adults or children would need to have their address registered with the state (McSherry, 2013). From this, the law was developed to allow for 'community notification' of registered sex offenders, which meant that a registered offender's conviction record would be public record, although public access to this record varies from state to state (McSherry, 2013). Finally, an amendment to the Jacob Wetterling Act in 1996, Megan's Law, named after another high profile child sex offender case, gave enforcement agencies the power to release 'relevant information' regarding the offender that would be considered necessary to protect the public (McSherry, 2013). Such laws create a sense of continuing, lifelong imprisonment without the physical barriers of prison walls. Offenders who are deemed dangerous enough to be registered as such by the State are bound to a life of branding and, in some instances, are not given the privacy or opportunity to redeem their past behaviours. Developments in dangerousness legislation in the US has created a trend whereby sex offenders will most likely never again able to lead normal lives.

There has been research which finds that it is difficult to measure the effect of registration schemes. Distinguishing the impact of being registered as a sex 
offender cannot easily be distinguished from other factors such as treatment programmes or sentencing practices and demographic changes (Harrison, 2011; McSherry, 2013). In addition, there has been very little research into the costs and benefits of sex offender registration schemes (McSherry, 2013). Therefore, there is a trend across Western societies to implement laws which 'name and shame' dangerous offenders and which could potentially hinder any progress made by the offender, without any knowledge of the effectiveness of such schemes to justify the intrusion and potentially negative effect of these schemes. An example of this is the Australian state of Victoria following its Queensland neighbour and US trends by enacting the Sex Offenders Registration Act in 2004 (McSherry, 2013).

States across Australia also introduced offender supervision schemes under numerous legislative provisions to monitor and manage offenders after they have completed their prison sentence. These orders generally contain a number of conditions which operate like bail or parole conditions in that, if they are breached, the offender is subject to prison recall (McSherry, 2013). In 2006, in the case of Attorney-General (Queensland) v Francis, which was similar to the UK case of Wells v Parole Board (2007), the circumstances of which eventually lead to the abolition of IPP (Imprisonment for Public Protection) sentencing laws in the UK ${ }^{19}$, the Queensland Court of Appeal expressed the view that supervision orders were preferable to a continuing detention orders as supervision of an offender was less punitive than detention. Francis had been detained for a further term after the end of his original sentence due to the perceived risk of his dangerousness. Under the Queensland Dangerous Prisoners legislation ${ }^{20}$ an offender could be placed under a continuing detention order where there was thought to be a continuing risk of sexual harm to the community. The Court noted that, in cases of preventive detention, it needs to be certain that there are exceptional reasons for the

\footnotetext{
${ }^{19}$ IPP sentences allowed for a prisoner to remain detained indefinitely, on the basis of public protection, after the original sentence had been completed. This point is discussed further below.

${ }^{20}$ Dangerous Prisoners (Sexual Offenders) Act 2003
} 
extreme intrusion on an offender's liberty. Hence, supervision orders are considered the preferable method to manage risk to society, but the Court needed to be satisfied that the risk could be sufficiently managed with a supervision order which would require the government department responsible to provide the resources necessary for this to occur. Although supervision schemes are intended to be used as a safer way to reintegrate offenders back into the community (McSherry, 2014), in most instances there is not enough resource or funding to allow for the least intrusive option whilst ensuring there is sufficient community protection (Francis, 2006).

This has been the case in Australia, where there have been practical problems with finding suitable accommodation for offenders who could be placed under a supervision order. Most offenders are isolated, with no community or family support which, in turn, increases the risk of reoffending (Wilson, 2008). The result of this gap in reintegration plans has been to build housing inside prison grounds to accommodate offenders. The Supreme Court of Victoria, when conducting judicial review of the decision from Fletcher $v$ Secretary to Department of Justice and Anor $^{21}$ (2006) found that this did not meet legislative requirements for an offender to be 'released into the community' (McSherry, 2013). The Court determined that, although the land was no longer deemed to be 'prison property', the houses built were still within prison walls and movement was, hence, severely restricted.

The result of this Court ruling was a legislative change by the Victoria State Government. The legislation was amended so that in such situations an offender would be deemed 'released into the community' even though they were still living a restricted life inside prison walls. This makes Australian laws comparable to that of the United States civil detention regime. This is because although supervision schemes were originally a less intrusive means to control and manage dangerous

${ }^{21}$ Fletcher v Secretary to Department of Justice and Anor [2006] VSC 354. 
offenders, gradual amendments have resulted in them having little or no difference to preventive detention (McSherry, 2013). Offenders are rarely released from prison, and rarely provided an opportunity to reintegrate into the community.

However, the Victoria State Government response to housing offenders on prison grounds could be because there is little research to support the effect of supervision schemes on reoffending. McSherry (2014) has found that such schemes are generally resource intensive and expensive. To be effective, supervision schemes need to target individual needs of offenders rather than implementing a blanket control and restriction of behaviours (McSherry, 2013). This would, therefore, require individual clinical assessments (McSherry, 2013), rather than broad general categories which are created depending on an offenders level of risk as high, medium or low (Hannah-Moffat, 2013; Simon, 2005). This would of course, be assisted if risk assessment was used in the criminal justice system for its intended purpose of establishing rehabilitative and reintegration needs of an offender, rather than the management and control purposes to justify and indeterminate sentence they are currently used for (Hannah-Moffat, 2005; 2013).

\section{United Kingdom, Canada and Germany}

England and Wales, Scotland, Canada and European societies provide varying degrees of measures for the management and control of dangerous offenders. The UK seems to have developed the most punitive and arbitrary measures, with broad ranging lifelong provisions solely for the purposes of protecting the public from dangerous offenders. In Germany, on the other hand, there have been successful challenges in the European Court of Human Rights, against preventive provisions that would have been in breach of fundamental human rights. However, the 
general trend is one in which states lean towards less ethical consideration when it comes to detaining offenders considered dangerous.

The first big expansion of penal provisions for dangerous offenders in England and Wales was through the introduction of Imprisonment for Public Protection (IPP) sentences in 2003. The purpose of IPP was to protect the public from offenders who had committed sexual or violent crimes which did not qualify for a life sentence, but who were considered too dangerous to be released from prison once they had completed their sentence (Harrison, 2011, McSherry, 2013). The IPP allowed for an indeterminate punitive sentence to be imposed on such offenders once they completed the sentence imposed for their offending. In order to be released under the IPP provision, offenders needed to show that there was a reduction in their level of risk. However, this was difficult to achieve due to a lack of access to rehabilitation and treatment programmes for offenders sentenced under IPP (Harrison, 2011).

IPP sentences were broadly defined, so that offenders considered to be low risk dangerous were also sentenced under the provision but with a shorter tariff period (Harrison, 2011). However, these offenders were considered a low priority for rehabilitation and treatment programmes. This, combined with the lack of access to programmes, resulted in these prisoners never being provided an opportunity to show that their risk to society was reducing. This resulted in low risk offenders being kept in prison long after their tariff had expired.

This sentencing regime caused numerous issues for the English prison and parole system. The broader issues at the time included the need to reduce the prison population. However, instead of assisting in reducing the prison population the IPP resulted in major prison overcrowding ${ }^{22}$, through imprisonment of what was meant to be a small number of dangerous and other high risk offenders (Harrison,

\footnotetext{
${ }^{22}$ Between 2003 and 2006 there were approximately 6,000 IPP orders made.
} 
2011). The subsequent introduction of a "low tariff" for some offenders, which was also intended to address the overcrowding problem created by IPP, only added to prison overcrowding further (Harrison, 2011; McSherry, 2013). This in turn resulted in increased pressure on the parole system, whereby many prisoners remained in prison after their sentence was complete, because they could not be processed through the system to be released (Harrison, 2011).

The IPP provision was abolished in 2012, after the European Court of Human Rights ruled in the case of James, Wells and Lee $v$. The United Kingdom ${ }^{23}$ that it was in breach of the European Convention on Human Rights. However, the amendment to IPP was not retrospective so, as at March 2013 , there were still approximately 5,800 offenders detained under IPP sentencing (Harrison, 2011). The remaining prisoners were informed that they would need to seek legal advice to challenge the decision made against them. A new sentence to address dangerous offenders was then introduced under the Legal Aid, Sentencing and Punishment of Offenders Act 2012. This Act introduced a 'mandatory' life sentence to be imposed for any offender appearing before the Court for their second serious offence, as defined in the Act. The Court is left with discretion to determine if a life sentence would be unjust in any circumstances. However, it is uncertain as to whether this sentence addresses any of the issues raised by the previous IPP sentence (Harrison, 2011).

England and Wales also introduced Multi-Agency Public Protection Arrangements (MAPPAs). The aim of MAPPAs was for agencies in England and Wales to coordinate to reduce risk and reoffending. Probation, Police and prison services were expected to work together in order to manage and monitor offenders in the community. Scotland also introduced a similar provision, initially to deal with sex

${ }^{23}$ (Applications nos. 25119/09, 57715/09 and 57877/09) 
offenders but then extended the provision to capture "restricted patients". These were offenders who had a mental illness which was related to their offending.

Although schemes such as the MAPPAs allow dangerous individuals to live outside prison, and are therefore a more ethical approach to managing dangerousness evaluations of such schemes have highlighted they are generally not effective (McSherry, 2013). This is due to lack of funding and support for administrative arrangements and a lack of coordinators to facilitate a cross-agency and crossborder approach to managing and monitoring dangerous offenders (McSherry, 2013).

The UK and Canada have also used civil commitment orders (McSherry, 2013). Their legislatures have taken advantage of civil orders to impose a number of conditions in order to monitor those who are at risk of sexual offending. A criminal sanction is imposed if these orders are breached. It appears that civil orders were used as an opportunity to monitor dangerous offenders without detaining offenders in prison or completely removing fundamental rights, whilst still protecting the public. However, what is most problematic about these orders in England and Wales is that they can be imposed on an individual who does not have any prior convictions if the judge is able to determine there is a high chance the person in question will commit a sexual offence in the future (McSherry, 2013). It seems that because of their very controversial nature, these orders have rarely been used (McSherry, 2013).

Along similar lines, in 2003 Scotland introduced a system, described as a hybrid of indefinite sentencing and a post-sentence supervision order, to impose lifelong restrictions on high risk offenders. The order can only be imposed by the High Court, before sentencing and with a supplementary risk assessment order. The order is imposed on the balance of probabilities that the offender will pose a risk to the public, rather than the higher criminal burden of beyond reasonable doubt. 
Furthermore, the order can be imposed with only one prior conviction of a violent or sexual offence. These recently developed provisions indicate, not only the prominence of risk assessment in the justice system, but also the lack of ethical determinations when dangerous provisions are legislated. It seems there is no consideration that an offender's liberty is completely taken, on the basis of a risk assessment that they may possibly commit a crime in the future, as protection of wider society is the more paramount consideration. Furthermore, there does not seem to be any thought to the living conditions for these offenders and in most situations they continue to be detained in maximum security units in prison.

Many of these provisions also seem to have constitutional legitimacy, meaning any detention or confinement based on dangerousness laws can only be challenged on human rights grounds. It is in these instances that the importance of external judicial bodies in order for an impartial judgment on domestic law becomes apparent. It is also important to have some form of independence and ability to challenge populist laws that are often made by legislatures, as with European Court of Human Rights. Furthermore, although control and supervision orders may provide some protection by reducing a small risk, the conditions attached to such orders can be highly restrictive thus limiting normal day-to-day interaction. Finally, supervision and control orders are expensive and the longevity of such orders is therefore questionable.

\section{Management, control and detention of dangerousness in New Zealand}

The 1954 Criminal Justice Act first introduced preventive detention as a sentence (Gavaghan et al., 2014), intended to be 'rarely' used for high recidivist offenders or sexual offenders against children. In the 1967 amendment to the Act, the sentence was then abolished except for offenders who committed sexual offences. It had been determined at the time that the best approach would be to not impose 
indeterminate sentences at all, rather than risk a sentencing regime which could not be justified (Gavaghan et al., 2014).

Since the 1980s, New Zealand penal policy and law has developed in similar fashion to the rest of Western society. Preventive detention became more of a prominent sentence, despite the strong arguments against such provisions (Penal Policy Review Committee Report, 1981; Floud and Young, 1981; Gavaghan et al., 2014). A significant shift which saw a lack of professional and, consequently, ethical consideration and a departure from the standard principles of sentencing (Gavaghan et al., 2014) came about after the 1999 New Zealand general election. The Labour Government gained power and the Minister of Justice gave a stern warning to the judiciary that they would lose their discretionary power if longer sentences were not imposed (Pratt, 2007). This was what the public had called for, it was claimed, so the Government intended to make sure harsh prison sentences would be delivered (Pratt, 2007). A judicial complaints process was established to oversee monitoring and discipline of judges as a symbolic move to show that the Government's direction needed to be taken (Pratt, 2007). This populist sentiment continues to be reflected through the media and lobby groups such as the Sensible Sentencing Trust. In what seems to be a move by successive governments to keep up with the publics' demand for 'justice', New Zealand has expanded preventive sentencing provisions with the use of court orders, similar to those in the US, UK and Australia. The first of these orders was the Extended Supervision Orders (ESO), followed by a civil detention regime with Public Protection Orders (PPO). As the ESO and PPO have recently been enacted, there is still research lacking in this area, however, the Acts provide that they will be of similar effect to those provisions that have been enacted in Australia and the US. This is inferred because of the nature of the orders and how they can be imposed as well as their far reaching scope for monitoring and detaining offenders.

\section{Extended Supervision Orders}


ESOs were established under the Parole (Extended Supervision Orders) Amendment Act 2004, for the purpose of monitoring serious sexual offenders. In 2014, the Parole Act was amended again in order to expand the ESO provision to include a range of sexual and violent offences which can qualify for an ESO and to allow the order to be renewed 'as necessary'. This essentially meant that there was no fixed end date for an offender's ESO, as Corrections could continue to request a renewal of the order, based on perceived risk of harm to the public. The Court was also given the power to impose special conditions for intensive 12 month monitoring when an offender is first given an ESO. The justification for the expansion was that it would 'minimise risk of serious harm to public' (as stated in the Department's website). However, it is difficult to find any evidence to support this claim. International research, as discussed above, indicates that there is not yet enough evidence to support the effectiveness of civil commitment orders. This point was also noted in the Department of Corrections' Regulatory Impact Statement (RIS) for the Bill (2014).

Under the provision, the Department of Corrections has the ability to apply to the sentencing court (this would usually be the High Court) for an ESO. The Court then assesses whether the offender in question meets the requirements under the Act to determine if an ESO should be imposed. These requirements include a conviction and sentence for one of the qualifying offences and an assessment which indicates the offender is a real and on-going risk of further sexual or violent offending,. If an order is imposed by the Court, Corrections can monitor the offender for up to 10 years.

The Department of Corrections ${ }^{24}$ describes the ESO as a means to "both monitor and manage the long-term risk posed by a high risk sex offender or a very high risk violent offender" in the community. The Department also claims "the offender remains visible to relevant agencies so that any risk is quickly identified and

\footnotetext{
${ }^{24}$ As per the Department's description on their website: www.corrections.govt.nz
} 
managed by the right people" and that there are 'relapse prevention strategies'. However, it is questionable as to how successfully this works in practice due to the resource and costs involved with supervision orders (McSherry, 2013).

Offenders who are subject to an ESO have requirements similar to parole, meaning they:

- are required to report to a probation officer regularly

- may need to attend treatment programmes and counselling

- will be subject restrictions on where they can live and work

- will be subject to restrictions on who they can interact with, and

- may be subject to electronic monitoring.

In the most extreme situation, an offender may be monitored 24 hours a day for the first 12 months.

There are a number of comments made in the Corrections RIS as to why the 2014 amendment to the Act was needed to broaden the scope of ESO. First, the RIS acknowledges ESO are targeting a group of offenders with a low re-offending rate and, therefore, it is unknown whether imposing an ESO will have any impact on further reducing the re-offending rate. The RIS then explains their reasoning for requiring expansion of the timeframe for an ESO. One of the initial comments is that "there are gaps in the Department's ability to effectively managing (sic) the long-term risk of serious harm to the public posed by the highest risk offenders...". They further state that an ESO is the best solution which complies with human rights obligations as there is not as much of an intrusion on the offender's rights as there are with other methods.

There is also a discussion of provisions in Australia and the UK as international models of practice to deal with dangerous offenders, in which there are "no evaluations on the effectiveness of these orders". What the RIS does not mention is that provisions in both Australia and UK have been challenged in Courts, with 
more of a change resulting in the UK due to their international human rights obligations. In Australia, the Victorian State Parliament changed legislation so that the Court-deemed 'non-compliant' parts of legislation did end up being compliant (McSherry, 2013 re: Fletcher v Secretary to Department of Justice and Anor). There appears to be no analysis of why a 10 year period is needed for an ESO. The RIS merely states that sex offenders can sometimes not reoffend for periods of 10 years and, therefore, extended ESO measures are needed as part of a range of measures to manage offenders and minimise harm to the public. There seems to have been an assumption that long periods of time between offences means that an offender should be subject to monitoring and control for longer. However, this is not necessarily the case. If it were so, there would be no boundary to allow the offender in question to have their autonomy (Floud and Young, 1981).

A secondary policy objective noted in the RIS was to consider "cost effectiveness and justice sector integrity" through the ESO process. It seems that the thinking behind this would have been that monitoring a dangerous offender through an ESO would be a more cost effective and ethical option than preventive detention. However, it is also possible to reduce cost and justice sector integrity with a less intrusive method of supervision. The New Zealand Law Society (submission to the Law and Order Select Committee, 28 October 2014) expressed concerns that the ESO amendment would create double punishment because the renewal period for consecutive ten year time periods would basically create another indeterminate sentence. This is especially so because ESO's are a criminal penalty as opposed to civil in most other countries. The Attorney-General had reported that the amendment to extend the ESO would be inconsistent with the Bill of Rights Act, with regard to retroactive penalties and double jeopardy. The Law Society supported this view and commented in its submission that the House should consider if the Bill's policy objectives could be progressed in a manner that is not as restrictive on fundamental rights. However, these concerns were not taken into 
consideration and the provision was passed. Therefore, it seems the additional policy intent regarding 'justice sector integrity' was not achieved with the ESO.

Furthermore, if an ESO is a satisfactory option and Corrections can provide the requisite management and monitoring of dangerous offenders, it is questionable why this method is not used more often than preventive detention. Although it is still restrictive and intrusive, especially the provisions for more serious cases, but nonetheless it would be the more ethically sound option as the ESO would allow the State to monitor an offender for any risks of harmful action and those risks could then be mitigated with intervention with aide of risk assessment tools.

\section{Public Protection Orders}

Enacted under the Public Safety (Public Protection Orders) Act 2014, a PPO is a civil order. In a paper delivered at a symposium for civil detention order run by the Equal Justice Project (2012), PPOs were described as "structurally and effectively similar" to the English IPP regime. Similar to the ESO, the Department of Corrections makes an application to the High Court for any serious sexual or violent offender nearing release date from a finite prison sentence. This includes an offender who has served a similar qualifying offence in an overseas jurisdiction. The Court needs to be satisfied to a 'high threshold' that there is a very high risk of imminent serious offending and that the considered individual displays high level of the following characteristics:

- an intense drive or urge to commit a particular form of sentencing

- limited self-regulatory capacity

- lack of concern or understanding of the impact of their offending, and

- poor personal relationships, or social isolation, or both.

For each application, Corrections needs to supply at least two reports from health assessors (one who must be a registered psychologist) which show that the applicant displays the characteristics listed above. 
Once again, as with ESOs, there were a number of concerns raised in the AttorneyGeneral's Bill of Rights Act report to Parliament. There were concerns that PPOs would ultimately be imposing further, and potentially indefinite, detention and restrictions on offenders who had already served a finite sentence. The powers provided in the PPO Act are far reaching and there is a high probability that those who receive a PPO will never be released (Finlayson, 2012). Furthermore, detainees under a PPO would be subject to the same conditions as prisoners, that being all correspondence, phone calls and visits would be managed and maintained by prison guards and any work opportunities would need to be within prison grounds. Nonetheless, the overall finding was that the PPO regime was justified as it would be dealing with the most dangerous offenders and there was a legitimate interest in protecting the public from them. The report looked into cases from the European Court of Human Rights and found civil commitment regimes have been upheld as long as they are grounded in expert evidence and that such orders are subject to ongoing review. ${ }^{25}$ There also needs to be a consideration of whether the detention is undertaken in a clinical and therapeutic context, which the PPO regime claims to satisfy as there is a requirement for behavioural risk assessments and the offender subject to a PPO are given a 'personalised management programme' with a view to release (Finlayson, 2012).

New Zealand's regime, with the Bill of Rights Act provisions, is well suited for the 'just re-distribution of risk' theory that was proposed in the 1981 Floud report. The above discussions on the PPO and ESO indicate a justice system where there is an allowance for some rights to be justifiably restricted. This is reflected in the New Zealand Court of Appeal decision in Belcher $v$ Chief Executive of the Department of Corrections ${ }^{26}$ which looked at the distinction between penal and civil measures in light of ESO and found that the structure of the New Zealand legal system allowed for such measures of public protection. It was also on this basis that the Court held

\footnotetext{
${ }^{25}$ The case used for this point was A v New Zealand (CCPR/C/66/D/754/1997).

${ }^{26}$ Belcher v Chief Executive of the Department of Corrections [2007] 1 NZLR 507.
} 
that rulings from similar cases, such as the Australian case of Fardon, did not apply to New Zealand's regime. However, it does raise the question as to why there continues to be a punitive preventive detention sentence when there are other less intrusive measures available for public protection purposes.

An example of this is seen in the case of $M v$ Germany, where although the European Court found that the sentence of preventive detention imposed on the applicant did breach the European Convention of Human Rights Article 5 (right to liberty) and Article 7 (no punishment without law), ${ }^{27}$ there is helpful discussion in the case regarding the detention standards and conditions for those offenders sentenced to preventive detention. ${ }^{28}$ In the case, there is discussion of the German Criminal Code provides that the German preventive detainee has the right to work, is provided with more 'pocket money' than regular prisoners, is able to wear and wash their own clothes, and is allowed longer visiting hours. Other differences between the preventive detainee and regular prisoner included a lack of cell confinement, where the preventive detainee is allowed to use the sports room and able stay outside in the yard for several hours every day. Preventive detainees were also allocated more 'comfortable' cells with additional furniture and equipment. This is significant, because although Germany, like most Western States, finds that preventive detention is necessary for the purposes of public protection (provisions were introduced into the German Criminal Code specifically to provide for sentences allowing 'correction and public protection') there also seems to be recognition of the unusual nature of the sentence. Hence, Germany provides as 'normal' a living situation for the detainees as is possible. In addition to material differences, there are also significant differences in prison practice, in

\footnotetext{
${ }^{27}$ The ECHR found that the breach to the Convention was a result of the retrospective application of the German Criminal Code to the applicant. A further term of imprisonment should not have been imposed on $\mathrm{M}$ as the amendment to the German Criminal Code occurred after his original sentence had been ordered. Hence there was a breach to M's right to liberty as well as a breach resulting from a punishment imposed without law.

${ }^{28}$ M v Germany (Application no. 19359/04)
} 
comparison to New Zealand, which are notable from this case ( $M v$ Germany, 2009). Preventive detainees are offered weekly discussion groups where they meet and consider potential recreational activities as well as how learning how to structure daily life routine ( $M \vee$ Germany, 2009). If needed, detainees are also offered one on one therapy sessions with a psychologist. These differences indicate a strong practice of assisting detainees with reintegration into society ( $M$ $v$ Germany, 2009) rather than in New Zealand, where the underlying assumption seems to be that the offender will never get out. ${ }^{29}$ This of course is not assisted by the fact preventive detainees are not considered for any treatment or rehabilitation programmes until they are nearing their parole date.

There are some important differences between the New Zealand legislative schemes and that of Australia, the US and the UK, most notably New Zealand has a more streamlined legislative regime compared to that of its Western nation counterparts. In addition, there has not been an extensive use of the ESO and PPO regimes, probably because these are newer regimes. It is hoped that legislative provisions which restrict the liberty and autonomy of offenders being used in a minimal manner and for exceptional cases. However, there are still other mechanisms that the New Zealand regime can adopt to alleviate some of the ethical dilemmas with detaining dangerous offenders. A first step would be to initiate separate living conditions, akin to that described in the case of $M v$ Germany for German preventive detainees.

Where there is a need in society to keep dangerous offenders detained, the ethical means to do so would surely be the least intrusive way possible (Fletcher $v$ Secretary to Department of Justice and Anor 2006 cited in McSherry, 2013). Furthermore, the use of electronic monitoring and probation programmes could also be improved so that an offender's risk can be monitored and there can be

\footnotetext{
${ }^{29}$ There is evidence of this in Chapter 5, where I analyse and discuss case files of preventive detainees in New Zealand.
} 
sufficient integration support provided, with the least possible intrusion on an offender's liberty. It seems that there is capacity for these changes to be implemented, considering self-care units and monitoring and supervisions regimes are already in place in New Zealand. However, the issue is that public protection now has a higher political and ethical priority than the rights of individual offenders, and it is not certain if a balance in rights and ethics to this situation can be achieved (Magee, 2013). 


\section{Chapter Five: Preventive Detention - How Does it Work in New Zealand?}

This chapter will investigate the practice of preventive detention sentencing in New Zealand, the level of ethical consideration in the detainment and risk assessment of dangerous offenders, and the role of the Parole Board. In order to complete this analysis and evaluation of the sentence in practise, I will utilise the case files of three New Zealand preventive detainee prisoners. This chapter will focus on the themes emerging from the files: the prominence of risk assessment in preventive detention, the detrimental effects of media reporting on their cases, and the effects of penal populism resulting in over-cautious decision. The case files used for this research contain information relating to each detainee's legal files. These include psychological reports, parole board hearing transcripts, sentencing notes and judicial judgements. All of the detainees are still imprisoned, and information for this research and chapter has been anonymised. The documents contained in each detainee's file are summarised, and the contents of the files are discussed to assess whether or not in practice the ethical dilemmas associated with preventive detention are reasonably addressed and mitigated. The Victoria University of Wellington Ethics Committee approved the collection of this data, on the provision that information contained in the files remained confidential and that the information was anonymous in the thesis. ${ }^{30}$

There were originally six case files but, due to unforeseen circumstances, three which had been authorised for use in this thesis were inadvertently destroyed in the legal office where they were being held. Furthermore, there is some discrepancy between documentation contained in each existing file, due to relevant papers being destroyed. The files and certain documents were unintentionally destroyed for the purposes of prudent legal practice by the lawyer

${ }^{30}$ Victoria University of Wellington Ethics Committee, Ethics Approval: No. 19450 
who agreed to assist with my research by providing access to files with detainee consent. Nonetheless, from the information available, there are clear themes that emerged, which indicate how the lack of weight given to ethical considerations has resulted in longer periods of detention. However, there are also some positive aspects, specifically the role of the Parole Board.

\section{Case files, methodology and preventive detention in practise}

\section{Case A}

Due to the requirement to maintain anonymity of research subjects, 'Case File $A$ ' will correspond with 'Offender A'. This will be applicable for all three files in this thesis. All documents in each file were read and summarised in order to determine themes which arose. The themes relate to arguments made in previous chapters regarding the history and development of preventive detention law and policy, ethical dilemmas of risk assessment and the rushed development of legislation regarding the management, control and detention of dangerous offenders.

Case File A contains Offender A's sentencing report, Parole Board reports, psychologists' reports (from both the Department of Corrections and independent psychologists) and other submissions that were made to the Parole Board regarding Offender A's risk at each hearing. The documents are provided up to, and including, Offender A's 2012 parole hearing which was declined on the basis that he continued to pose a risk to society.

Offender A was sentenced to preventive detention in 1995, after serving three prior prison sentences for indecent offending against boys under the age of 16. At his sentencing the Judge noted that although the offence was not a "serious one of its type" preventive detention was warranted because of Offender A's persistent offending, his neglect to heed warnings of an indeterminate sentence and his lack of willingness to accept responsibility for his offending. 
At the time of Offender A's 2012 parole hearing and decision, he was in his mid70 s and was suffering from a number of health issues. However, it was only after this decision by the Parole Board that they considered a risk assessment which would take account of Offender A's age and health and the impact these factors would have on any potential offending.

Prior to this last record of parole, Case File A provided insight into what other factors were being considered in relation to Offender $A$ and his release. In 2005, once Offender A was close to parole eligibility, a sentence plan was developed which outlined key rehabilitation activities and goals for him to work towards in order to facilitate his release. It is of note that this plan, which included a rehabilitation and treatment plan, was only established after Offender A had served 10 years in prison. During his earliest parole hearings there were clear themes, most significantly Offender A's lack of recognition of his offending, which in turn posed a barrier to him accessing rehabilitation opportunities provided by the prison. Consequently, the lack of rehabilitation or other treatment hindered his release as he did not have the mechanism to show his risk of offending has been reduced. Another significant concern noted in psychologists' reports to the Parole Board was the lack of family or community support that Offender A had, which increased his risk of reoffending. However, at his 2012 hearing he had completed the requisite child sex offender programme offered by the Department of Corrections (the Te Piriti programme) ${ }^{31}$, had made progress in developing a community support team and had agreed to electronic monitoring. Nonetheless, his parole was again declined on the basis that the Board held that he continued to pose a significant risk to society. Case File $A$ indicates that a stringent plan had

\footnotetext{
${ }^{31}$ Te Piriti is a Special Treatment Unit for child sex offenders, situated at Auckland prison, established in 1994. It is a cognitive behaviour therapy programme, focused in a tikanga Maori framework. An evaluation of the programme has found it to have significant positive effects on Maori reoffending rates, see: Nathan, Wilson \& Hillman, 2003. Tikanga Maori, as per the Maori Language Commission's definition: can be described as general behaviour and guidance for daily life and interaction in Maori culture and custom (http://www.tetaurawhiri.govt.nz/learn-te-reomaori/tikanga-maori//).
} 
been developed to provide a supportive reintegration with electronic monitoring to allow Corrections to manage his location soon after release as this was when he was most at risk of committing offences. However, instead of progressing his reintegration plan, parole was declined. At this point, the documents on file note his deteriorating health, partially as a result of his advanced age.

The ethical dilemmas that arise with Case File A, are those associated with risk assessment and methods of detention. Through the file, there are conflicting reports from psychologists regarding Offender A's risk to society, which would make the decision a difficult one for the Parole Board. This is because the Board is required to make a judgment based on the evidence that is provided. However, where there are conflicting clinical reports, it is more likely the Board will make a cautious decision to keep the offender in prison until there is some consistency in the offender's reports. In this Case, the Department of Corrections' psychologists seem more focused on Offender $A^{\prime}$ 's risk rating, whereas independent psychologists are focused on Offender A's ability to address his risk factors for reoffending and utilise mechanisms to mitigate risks. An example of this is his work on developing relationships with members of his community who have agreed to assist him with accommodation and other support he may need to reintegrate back into society. What is observed in Case File A is the tendency for the Parole Board to make a cautious decision which heavily relies on reports that are presented by Corrections.

The reasoning of the Board is not documented in the file. However, there are a number of possible explanations for the Board's reliance on reports submitted by the Department of Corrections. First, Corrections has the ability to monitor the offender in his day-to-day life in prison, whereas an independent psychologist makes an assessment based on what they see in each appointment. In addition, the Corrections reports to the Parole Board contain a number of actuarial risk assessment scores. However, in this instance there are a number of other factors 
which could have allowed the Parole Board to make a less cautious decision. In particular, Offender A agreed to electronic monitoring. This would provide an additional element of risk mitigation in addition to him having a place to reside with people who agreed to support him. There was also consideration given to Offender A's age and health condition. Despite these factors, the Board did not grant Offender A parole. This could be explained by the fact that the preventive sentence was imposed on Offender $A$ at a time when society was calling for harsher sentencing and a tougher approach to crime in general. As discussed in Chapter two, it was during the 1990s that penal populism was resulting in a 'tough on crime' agenda from politicians (Pratt, 2007; 2013). As a result, the judiciary was essentially required to impose harsher sentences based on public preference (Pratt, 2013). By the time Offender A was eligible for parole, around 2005, there was a strong presence of lobby groups, such as the Sensible Sentencing Trust, who by this time had come to have a prominent voice in stronger sentencing (Pratt and Clark, 2005). This also occurred after the enactment of the Sentencing Act 2002 and a direction from the Government to Judges for longer, harsher sentences for crime as well as the establishment of the Judicial Complaints Authority (Pratt, 2013). This would explain the overly cautious approach taken by the Parole Board, which is usually chaired by a Judge, given that the File indicates number of factors which favoured an opportunity for release.

\section{Case B}

Case File B contains transcripts from Parole Board hearings, psychologist reports, Parole Board and Department of Corrections operational manuals, sentencing notes, affidavits from court proceedings, email and other communications between Department of Corrections staff members and media clippings related to Offender B's release. The documents range in date from 1988 through to 2003. 
Offender B was sentenced to preventive detention in 1988, when he was 27 years old. He pleaded guilty to three charges of sexual violation by rape and one charge of abduction. Offender B's victim provided a statement to the Court, saying she had concerns for the protection of others, which was taken into account at his sentencing. The sentencing Judge also considered the offender's personal history, noting that Offender $B$ had been abandoned by his mother and raised in 'disturbing circumstances' which involved neglect, physical abuse and poor health. Offender B was committed to Lake Alice Psychiatric Hospital ${ }^{32}$ by the time he was 18 years old, where he suffered further abuse.

A report provided by a probation officer to the Court noted that a finite sentence would help to support a more positive outcome for treatment of Offender B. However, the Judge could not see any other reasonable solution other than a sentence of preventive detention. On the basis of the evidence that was submitted to the Court, there was a strong indication that Offender B would reoffend against women and, hence, there was a strong public protection element to this case. The Judge also noted that the sentence was 'drastic' and without a time limit, only the entitlement of parole review after 10 years. The Judge echoed a prior psychologist's report on Offender B and stated that imposing the sentence of preventive detention "is an admission of society's failure". This comment from the Judge at the time, and an acknowledgment of Offender B's difficult upbringing, reflects that there were social circumstances which contributed to Offender B's behaviour and subsequent indeterminate sentence, a reminder of the ethical dilemmas intrinsic to preventive detention. Rather than being offered rehabilitation to address his learned abnormal and harmful behaviours, Offender $B$

\footnotetext{
${ }^{32}$ Lake Alice Hospital was closed in the 1990s, as a result of the decline of effectiveness of psychiatric institutions in New Zealand society. A claim brought against the hospital found that between 1972 and 1977 the staff subjected adolescent patients to abuse and mistreatment such as unmodified electroconvulsive therapy. In 2001, then Prime Minister Helen Clark apologised on behalf of the New Zealand Government and 150 patients received compensation for the abuse they were subjected too. Offender B was among the 150 patients. See http://www.lakealicehospital.com/
} 
was indefinitely detained as a measure to protect the public. Offender B currently remains in prison and his last parole hearing, in 2015, indicates he will continue to be so for the foreseeable future. ${ }^{33}$ However, it was recommended he begin to transition to a self-care prison unit.

This file contains documents which explained the Parole Board's use of the Structured Decision Making ('SDM') system to determine whether or not to grant parole. The system was developed by the Department of Corrections and contains three assessments which include: the Risk Assessment Instrument (an actuarial based tool designed to assess risk of conviction); the Psychopathy Check List ('PCL' a long standing clinical assessment tool used to assess personality); and the Needs Analysis Questionnaire ('NAQ' which is based on an interview with the offender to determine risk areas that need to be worked on; it includes questions about drinking and drug use habits, family and support, work and skills, and prison activity such as good or bad behaviour). The NAQ is not based solely on what the offender says, responses are verified from other sources where possible.

The outcome of the SDM system is a risk rating between $A$ and $E$ given to the offender, where $A$ is low risk and $E$ is high risk. Where an offender is at risk rating $E$, there are very limited opportunities for the offender to work or participate in rehabilitation programmes. This is especially problematic for preventive detainees, as the nature of their offending and, in most cases, their personal circumstances (such as mental health, and long term drug and alcohol dependency) means that they are less likely to reduce their risk rating to a level which allows them to take up opportunities which in turn will facilitate a further reduction in their risk profile. Furthermore, preventive detainees are only provided with a rehabilitation plan when their parole eligibility date is near (this is usually after 10 years'

\footnotetext{
${ }^{33}$ This source was not contained in the file, it was located online at the Parole Board website: http://www.paroleboard.govt.nz/
} 
imprisonment), further reducing opportunities to reduce their risk rating from $D$ or E to an acceptable level for reintegration programmes.

Nevertheless, the SDM system continues to be used at every parole hearing, usually once a year from when the offender is eligible for parole, which in and of itself is not a helpful tool in practical terms as it would need to be interpreted by a clinical professional versed in the tool itself. The SDM provides a checklist of questions which are answered by the offender and prison manger or psychologist and the information is then collated to provide the risk rating. There are no recommendations as to what can be done to reduce the risk level of an offender. It is only when considering the whole selection of evidence that is considered by the Parole Board, which contains more detailed interviews and clinical recommendations, that there is any practical guidance as to how the risk assessment can be used for its purpose of facilitating an offender's release. However, even then, for the subjects of this study, it seems it is a long and difficult path to get to a point where they can be considered for movement out of mainstream imprisonment and into self-care re-integrative units.

An analysis of the parole hearing transcripts from 1997 through to 2003 indicates the changing nature of the role of the Parole Board. From parole hearings one through three (spanning from 1997 to 1999) there were a number of planning recommendations from the Board. The members of the Board asked Offender B a number of questions to ascertain what areas in particular he would need to work on to facilitate his release. Offender B was noted as saying to the Board at his 1999 parole hearing that he found the restrictive nature of his sentence very difficult as he was unable to apply for work or to participate in any programmes. The Board noted his concerns and attempted to address the means to reduce Offender B's risk rating in order to allow him to access opportunities available through the prison. Offender $B$ acknowledged that as part of his risk reduction he needed to work on his social skills and interactions with others. 
At Offender B's fourth parole hearing (in 2000) he is asked whether or not he has received any therapy for his past 'issues' at Lake Alice Hospital. Although Offender B's experience was mentioned by the sentencing Judge, this matter had not been raised by the Parole Board until this fourth meeting. The questioning from the Board seems to have been triggered by an incident in prison, whereby Offender $B$ threatened to assault a prison officer, and the Board recognised that it may be beneficial for Offender $B$ to address his anger and reaction to certain situations which generate anger. However in order to do this, Offender B needs to reduce his risk rating to that of 'low-medium' before becoming eligible for available programmes. Naturally, Offender B's question is how does he go about reducing his risk rating, and the response provided is an unhelpful and rather vacuous "with time and maturity". Furthermore, a panel member states to Offender B: "I can't think of any preventive detainees who've got out after 12 years" (the period of time he had been in prison for). This reflects a very negative attitude from State authorities towards preventive detainees that effectively reinforces the hopelessness of their position. Offender B has, in essence, been informed that he will need to wait and be calm in order to reduce his risk rating for an unspecified time, most likely a good number of years: as if the passage of that time means nothing at all to the Parole Board member, but means everything to Offender B. Nor is he given any direction as to how he is meant to spend his time meanwhile (cf Cohen and Taylor, 1972).

At Offender B's fifth parole hearing (in 2001), the situation worsened as Offender $B$ was informed there was a misunderstanding by the Parole Board that he needed to be low risk before he could apply to the Board for parole outings, which include escorted visits to places such as coffee shops and garden centres. Following this, the Parole Board recommended that Offender B should be considered for day parole and a preliminary reintegration proposal was developed. The following year, Offender B received a letter from the Parole Board informing him that as he 
had been incident free for 12 months, a release would be determined at his next hearing. Unlike Offender $A^{\prime}$ 's case where a release plan and provisions were determined but never followed through, Offender B was subsequently released on parole with conditions in 2003. One of the conditions imposed was a requirement to work with a psychologist as the Board felt the majority of Offender B's risk factors and offending were associated with the abuse he suffered as a child. Hence if he continued to work with a psychologist, his risk would be manageable. At this point, it seemed the Parole Board were willing to make ethical determinations in favour of this offender and allow for monitored and supported release of a preventive detainee, despite the Government's objective to keep dangerous offenders in prison.

However, this positive outcome was short lived, as less than 6 months after Offender B was released on parole, there was a major news story about the release of a rapist. There are emails in Case File B which indicate a potential leak from a Corrections staff member about Offender B's release and whereabouts. This was because of the depth of personal information that the media obviously had from its extensive and detailed reporting. The article mentioned his name and place of residence and the crimes he had been imprisoned for. There were a number of sensationalist headlines which followed, focusing on how the public's rights were being encumbered because of a release of an offender who had been sentenced to preventive detention. A Department of Corrections investigation into the matter was not, however, conclusive as to whether or not a staff member had leaked the information.

In order to "allay public concern" the offender's parole conditions were varied which resulted in Offender $B$ having to move out of his initial and chosen residential address into a residential rehabilitation centre for men who have been involved in criminal offending. There were further conditions also imposed regarding his curfew. However, Offender B's new residence was also released to 
the media and reported on widely, further creating a sense of fear and consequently isolating Offender B. The media attention caused him great stress which resulted in excessive alcohol consumption and sleeping away from the rehabilitation centre as a means to cope. This resulted in a prison recall order as he had breached his parole conditions, stimulating more media interest. At his recall hearing, instead of standing their ground that Offender B had shown significant progress in risk reduction and ways to cope with his risk factors, the Parole Board determined that if his release meant surveillance and supervision would be needed, this was an indication that his level of risk to the community was unacceptable. Thus, in this instance it seems the ethics were that public protection outweighed the rights of the individual, influenced by the freedom of the media to report on 'high profile' cases such as this. The Parole Board's preferred option seemed to be to keep Offender B in restrictive conditions, rather than offering him the chance and time to reintegrate into society, with the benefit to the public with monitoring and supervision to manage any escalated risk of Offender B.

Upon recall, the Parole Board did request that Corrections exempt Offender B from the usual protocols in order to obtain employment within the prison, participate in the self-care shopping programme and undertake supervised outings as this would be useful to help Offender B maintain the progress he had made regarding his reduced risk level. Corrections also recognised that a more stringent and staggered release plan would be required for Offender B's reintegration to be successful, to mitigate and manage his isolation and loneliness which had the potential to trigger his offending. Had it not been for the prominence of the media's reporting on this matter, this post-release support could have continued to be provided to Offender $B$ without a recall decision being made. 
Case C

Case File C contains reports of clinical psychologists (both from the Department of Corrections and independent psychologists) and psychiatrists from 1991 through to 2007, various court judgements regarding proceedings involving Offender C, and operational manuals regarding risk reports.

Offender C was sentenced to preventive detention in 1991, following his third conviction for rape. Offender C's first conviction was in 1983, he was sentenced to three years imprisonment as the Judge noted that he had not been 'violent' in his rape. Offender C's second conviction and sentence was in 1986, where he was sentenced to seven and a half years imprisonment. Offender C's psychologist's reports note that he had an abusive and violent upbringing, where he witnessed his father rape his mother on numerous occasions and, as a consequence, he had a negative and violent attitude towards women. In addition, Offender $\mathrm{C}$ had been in various institutions from as the age of eight. Offender $\mathrm{C}$ admitted on a number of occasions to psychologists that he did not know how to live in normal society without the restrictions of an institution.

Of the three case files that are the subject of this research, Case File $C$ gave the greatest insight into the reporting of psychologists and the differences in reports between a Department of Corrections psychologist and an independent clinician. The Corrections reports focus on keeping Offender $\mathrm{C}$ in prison due to concerns about his behaviour and attitude which are significant to his risk of reoffending. On the other hand, the reports from the independent clinicians are varied, some suggesting that there is no hope for Offender $\mathrm{C}$ and recommending that no further therapy is offered, and others are focused on what can be done to assist him facilitate a reduction in his risk factors. A report completed in 1991 noted that Offender $\mathrm{C}$ had a 'psychopathic personality disorder' and that there was a strong probability of him not being safe outside of an institution. It is for this reason the 
clinician claimed that there "no point" to attempt reintegration and the clinician would not support any changes to Offender C's risk or security levels.

In a report from 2003, an independent psychologist noted that Offender $\mathrm{C}$ had a strong willingness to be a better person and not be a risk to society, demonstrated through the progress he had made in managing his anger. However, he still required strong support and guidance in order to manage his behaviour and attitudes. In comparison to this, the 2003 report from a Corrections-employed psychologist presented an argument to keep Offender $\mathrm{C}$ in prison. There was no balance of positive and negative factors; rather, most of the report is a commentary on his aggressive behaviour towards other inmates and prison officers and his lack of ability to live outside of an institution. There is also a statement in the report that Offender $\mathrm{C}$ had declined any psychologist sessions on advice from his lawyer, and the clinician interprets this as "no motivation to address his offending".

The reliance on Department of Corrections reports is important. Although other evidence is considered by the Parole Board, Corrections seems to have the most influence when informing the Board about an offender's risk rating. This is not only because Corrections has developed the SDM system that is used to determine an actuarial risk rating for offenders, but also because Corrections staff have the most contact with the offender during day-to-day life in the prison. This raises the question of whether reports are impartial enough to determine the risk of an offender, but there is not enough evidence in Case File $C$ to make an inference on this matter. ${ }^{34}$ However, a chronology of the reports indicates that clinical perceptions and recommendations were not always negative or restrictive. There is also a common thread running through the psychologists' reports continuing to offer Offender $\mathrm{C}$ various rehabilitation and treatment methods that could help facilitate a reduction in his reoffending.

\footnotetext{
${ }^{34}$ Noting that transcripts from Parole Board hearings were not included in Case File C.
} 
Another significant issue that arises from Case File $C$, is the lack of rehabilitation and treatment programmes that are provided to offenders on preventive detention. Although Offender $\mathrm{C}$ refused to take responsibility for his offending and there are recurring observations from psychologists that Offender $\mathrm{C}$ is focused on being released rather than addressing his risk and offending factors, there are notes on file which indicate either the lack of appropriate programmes or an inability for Offender $\mathrm{C}$ to apply for a programme due to his risk rating. The latter situation creates the aforementioned perpetual issue where an offender needs to demonstrate a reduction in risk without having access to the tools to support this, and, as a result, remains in restrictive prison conditions.

The issue of no appropriate programmes to target offence factors is, however, a gap in Corrections' prison programmes that, in effect, victimises inmates such as Offender C. He was in a situation where he was not able to participate in a programme to address his violence as his violent offending is sexual in nature, and neither was he able to participate in the child sex offender programme, because he offended against adults. Thus, psychologists noted that the available programmes would not address his criminal offending factors. This point pertains not only to the ethics associated with risk assessment but also to detaining dangerous offenders without appropriate tools to facilitate a return to society. If there are no available programmes which address an offender's risk of offending factors, then it raises the question of how an offender is expected to ever be released.

Summary of findings and analysis - ethical dilemmas and preventive detention in New Zealand

Risk

From the files, there seem to be a variety of sources that are considered when assessing the risk of an offender by both the sentencing Judge and the Parole 
Board. This is especially important for the Parole Board as the Sentencing and Parole Act 2002 vested authority to the Board to make release decisions. Although there appears to be a focus on the actuarial risk assessments used by the Department of Corrections, there are also indications that the Parole Board used this information to make practical recommendations to facilitate release for the offender. This is a complex decision that requires considerable balancing of information that is presented and, for the most part, the Board makes decisions based on the best interests of the offender. However, a failure of the system can be seen through the process where rehabilitation and treatment programmes are not offered to offenders until they are close to parole eligibility. This creates the perpetual dilemma whereby an offender needs to demonstrate they are no longer a risk to society, but without assistance from rehabilitative programmes they are unable to adequately address offending and risk factors, thereby hindering any possibility of release. This process requires more than counselling sessions alone.

Where parole decisions seem skewed is when there is a strong media interest in a particular offender. For instance, there were a number of negative media stories, which sensationalised the extent of offending, regarding Offender A's impending parole hearing, which was denied. Another example is when Offender B was recalled to "allay public concern" due to the significant media interest in his parole release. It is seldom reported in the media that an offender on parole will be monitored and supported by probation services, only that an offender has been released and the public 'has a right to know', as was the case when Offender B was on parole. One media article goes onto state the safety of the community was at stake, while itself having no regard for the privacy and reintegration of Offender B.

The Board could also give more consideration or priority to the age and health of an offender when requesting psychologist reports. These would undoubtedly be important factors in assessing the risk of reoffending an offender would pose to the community, especially if an offender's health is significantly deteriorating. 
However, a number parole decisions published on the Parole Board's website ${ }^{35}$ indicate that the public interest continues to be the imperative consideration when parole decisions are made. Although procedural fairness is built into legislation, whereby offenders have the right to appeal decisions made by the Board, they are usually in a positon where they do not have any family or community support to assist them with such procedures. The analysis of Case Files A, B and C indicate the ethical concerns that were raised in the 1960 s continue to be prominent today through the practice of administering a preventive sentence. There is an indication that over-cautious judgments and exaggerated risk scores result in offenders remaining in prison for considerably longer than necessary.

\section{Methods of detention}

The method used to detain offenders is an area where it seems there is room for development in New Zealand's penal regime. Dangerous offenders are kept in mainstream prison cells, for the most part in maximum security due to their high security and risk ratings. This in and of itself is problematic as the detainees, who are in prison for considerably long periods of time, are living in extremely restrictive conditions. Furthermore, the high security and risk ratings prevent offenders from being able to take up rehabilitation programmes to address their offending. As discussed in Chapter 4, detention can become arbitrary where there is no provision of treatment or rehabilitation to facilitate release, and in instances where the offender is being detained in a manner that encroaches their liberty more so than the minimum needed to protect the public (see: discussion on case of James, Wells and Lee v. The United Kingdom and Fletcher $v$ Secretary to Department of Justice and Anor). The Case Files indicate that the Department of Corrections operational policy determines when programmes are available to offenders, and preventive detainees are not offered any programmes until they are nearing parole eligibility, due to resource and cost constraints.

\footnotetext{
${ }^{35}$ http://www.paroleboard.govt.nz/
} 
From Case File B and C, it seems there is also an issue with lack of resources to provide the support needed to an offender, who has been in prison for a substantial part of his life, and the lack of targeted treatment programmes for offenders. In particular, for Offender $\mathrm{C}$ there was difficulty in finding a programme that would target his violent behaviours and sexual attitudes towards adult women, as most programmes in New Zealand prisons are targeted at child sex offenders or violence alone.

This is problematic as by the time an offender reaches parole eligibility, the offender will be more strongly institutionalised and it becomes all the more difficult to learn and adapt new behaviours (Haney, 2002). Thus, the response to public protection is through keeping offenders detained rather than changing their behavioural needs.

\section{The effects of penal populism}

It is difficult to mitigate the far reaching effects of penal populism on parole decisions. As seen with Case Files $A$ and $B$, there appears to be a reluctance and hesitation to release offenders for fear of media and lobby group reactions. The media and lobby groups are critical of experts who are experienced in making decisions on dangerous offenders. Parliament gave a strong direction when the Sentencing and Parole Acts were enacted in 2002 that judges were to impose harsher and longer sentences for dangerous offenders. The role of the media exacerbates the problems associated with dangerous offenders and preventive detention as it provides a prominent platform for victims of crime who are encouraged by lobby groups to have a voice. This is in addition to sensationalist reporting and sometimes inaccurate information. During the course of this research, there were a number of articles relating to Offender $A$ and Offender $B$ which published varied differences of fact. The differences noted were usually the offences for which the preventive detention sentence was given to the offenders, 
in what seems to be an attempt to sensationalise the story as much as possible. Although the crimes that have been committed by this category of offender are generally the most serious, there is no portrayal of the offender's history which contributes to the story of how he has come to be in that position. This balance is by no means needed as a justification, but as a lesson to society on what it can do to try and prevent these offences, without keeping the offender locked up in prison. As a sentencing Judge from Case File B above said of preventive detention: "it is an admission of society's failure". However, it is one that can be remedied when there is an ethical foundation to penal policy and law development.

This would involve penal authorities such as the judiciary and the Parole Board to have more freedom in making decisions that are not only best for the community but also for the offender, such as greater use of electronic monitoring to allow for more parole releases. This of course, is not the easiest solution currently for a number of reasons. First, there is more research needed on the effects on recidivism from monitoring and supervision schemes on high risk offenders (McSherry, 2013). Second there is a need to devote more resource to focusing on the rehabilitation and other needs of high risk offenders (Hannah-Moffat, 2013). This is difficult when penal populism is still strong. It would seem another societal shift or change would be needed to re-centre the balance of criminal justice law and policy development across modern society. 


\section{Chapter Six: Conclusion}

This thesis examined the development and use of preventive detention in New Zealand to consider whether or not it is an ethically justifiable sentence. In considering this, law and practice across Australia, the US and the UK were examined to compare trends in preventive sentencing and monitoring practice across Western society.

New Zealand saw an increase in the use of preventive detention from the mid1980s (Meek, 1995). There had been a number of serious violent crimes that had been widely reported on in the media, which then caused increased fear of violent crime in the general public (Meek, 1995). From the on, the media reporting of crime increased exponentially and the influence of penal populism was growing, despite the official crime rate showing a decrease in serious violent offences (Pratt, 2007). As public fear of violent crime increased, the New Zealand Government responded by incrementally widening the scope of preventive sentencing provisions (Brown and Young, 2000; Hurd, 2008). The enactment of the Sentencing Act 2002 saw preventive detention provisions become the most liberal they had been throughout history, with the age of eligibility brought down to 18 and the list of qualifying offences expanded (Roberts, 2003). The Government made clear their expectation for judges to make more use of it by sentencing dangerous offenders indefinitely (Pratt, 2013).

The 1990s also saw the introduction of actuarial risk assessment in the criminal justice system (Gavaghan et al., 2014). This new risk assessment was considered a 'fool-proof' means to sentence dangerous offenders because of its scientific grounding (Gavaghan et al., 2014; Hannah-Moffat, 2013). Actuarial tools for risk assessment had been developed from the same tools that were used to calculate insurance premiums and were, therefore, considered more reliable and objective than clinical risk assessment which has previously been used as a means to predict 
the future risk of harm of an offender (Simon, 2005). However, the literature clearly indicates that there continue to be concerns with the use of risk tools in the penal system (Hannah-Moffat, 2013; McSherry, 2014).

The Department of Corrections in New Zealand uses the Risk of re-Conviction X Risk of re-Imprisonment model (RoC*Rol) as its main source to calculate an offenders risk level (Gavaghan et al., 2014; Magee, 2013). This risk tool was developed by, and later evaluated by, senior psychologists at the Department (Gavaghan et al, 2014; Magee, 2013). Although Corrections has found the tool to be a reliable predictor of risk, there are arguments to that the RoC* Rol is limited in its ability as a risk management tool for offenders (Gavaghan et al, 2014; Magee, 2013). This is because the RoC*Rol was developed on a system which does not allow for changing data that is pertinent to an offenders risk level, such as progress and completion of rehabilitation programmes (Hannah-Moffat, 2013; Magee, 2013). Neither does the RoC*Rol account for an offender's age or health, which McSherry (2014) has argued is essential to factor in for purposes of risk reduction. Risk tools which are used for prediction in sentencing have been developed from methods used to establish best fit treatment and rehabilitations programmes for offenders (Hannah-Moffat, 2013) which essentially means the RoC*Rol is not used for its original purpose (Magee, 2013). Furthermore, in the New Zealand Court of Appeal case of $R v$ Peta it was found that the RoC*Rol presented an incorrect score which was then interpreted incorrectly and provided to the Court as evidence for imposing a 10 year Extended Supervision Order (Gavaghan et al., 2014). Mistakes such as this have far reaching consequences and indicate that New Zealand's current methods for risk assessment in preventive sentencing are not ethically justifiable, as they can significantly encroach on a person's liberty based on a risk score.

A possible method to improve the ethical use of the RoC*Rol is through adapting the 'middle ground ethics' approach proposed by McSherry (2014). This would 
involve changing the framework around ethics and implementing clinical standards for psychologists to abide by. Both the framework and clinical standards would be based on the underlying assumption that there should always be some rehabilitation or treatment benefit for the offender, rather than a default position where there is no hope of an offender being released. To implement an ethical framework and standards, it is also recommended that an independent statutory body should be established to determine standards, issue guidance on risk practice, and accredit risk assessors. This would presumably consist of professionals from both the criminal and medical fields.

Risk assessment is not the only area in the overall preventive detention scheme that needs further development, if the sentence is to become ethically justifiable. New Zealand preventive detainees are held in mainstream prison cells and, in some cases, maximum security due to their security and risk rating. This means that they are kept in punitive and restrictive conditions for an indefinite period of time, and on the basis of public protection rather than a particular offence. An ethical approach is said to be one that had the least possible intrusion on the offender's liberty (Floud and Young, 1981; McSherry, 2013). With the development of supervision and monitoring regimes, it would seem that preventive detainees could be reintegrated into society more regularly as public safety could be accounted for with electronic monitoring. However, bearing in mind that this is not always the most secure option as electronic monitoring can be breached, preventive detainees should at least have less restrictive living conditions. Similar to the German preventive detainees ( $M \vee$ Germany, 2009), New Zealand could implement a system which allowed for greater freedom within the prison for them. This could include therapy sessions and other mechanisms which would assist the offender with living in society. There needs to be an element of addressing offending behaviours as a means to facilitate the release of detainees (Hannah-Moffat, 2013). As seen in New Zealand, preventive detainees do not have 
the option to take up any rehabilitation programmes until they are close to parole eligibility, which in most cases is at least 10 years into an offender's sentence.

An analysis of three Case Files of New Zealand preventive detainees reflects these concerns and continuing ethical dilemmas. Although the recommendations made from the findings in this thesis seem straightforward, it is questionable as to whether ethical dilemmas in preventive detention sentencing will be resolved anytime soon. There remains a strong influence of penal populism, a strong presence of victims' rights groups and an even faster, more sensationalised media reporting of these issues. These influences, in the meantime, will continue to guide government policy and law development towards a more punitive agenda (Pratt, 2007). As Magee (2013) has said, if preventive sentencing laws and practice cannot be improved then the provision should be abolished, but that is an option which is most likely politically unrealistic. 


\section{References}

$A v$ New Zealand, CCPR/C/66/D/754 (1997).

Bakker, L. W.; Riley, D.; and O'Malley, J. (1999). ROC, Risk of Reconviction: Statistical Models Predicting Four Types of Reoffending. Wellington, New Zealand; Department of Corrections.

Baxstrom v. Herold, 383 U.S. 107 (1966).

Belcher v Chief Executive of the Department of Corrections, 1 NZLR 507 (2007).

Black, J. (2011). Is the preventive detention of dangerous offenders justifiable? Journal of Applied Security Research, 6(3), 317-338.

Bottoms, A.E.; and Brownsword, R. (1982). The dangerousness debate after the Floud report. British Journal of Criminology, 22(3), 229-254.

Brash, D. (2004). Law and Order: A National Priority. An address to the Sensible Sentencing Trust. Accessed online at: www.scoop.co.nz/stories/PA0407/S00080.htm, date accessed: 9 January 2017.

Brown, M.; and Young, W. (2000). Recent trends in sentencing and penal policy in New Zealand. International Criminal Justice Review, 10(1), 1-31.

Butler, A.S. (2002). Limiting rights. Victoria University of Wellington Law Review, 33, 357-377.

Butler, P. (2006). 15 years of the NZ Bill of Rights: Time to celebrate, time to reflect, time to work harder? Victoria University Human Rights Research, 4, $1-31$. 
Commission of Inquiry (1983). Report of the Commission of Inquiry - The Circumstances of the Release of Ian David Donaldson from a Psych Hospital and of His Subsequent Arrest and Release on Bail. Wellington, New Zealand; New Zealand Government.

Cocozza, J. J.; and Steadman, H. J (1976). The Failure of Psychiatric Predictions of Dangerousness: Clear and Convincing Evidence. Rutgers Law Review, 29(5), 1084-1101.

Cohen, S.; and Taylor, L. (1972). Psychological Survival: The experience of LongTerm Imprisonment. Harmondsworth, United Kingdom; Penguin.

Council of Europe (no date). European Court of Human Rights. Accessed online at: www.echr.coe.int, date accessed: 10 January 2014.

Department of Corrections (2014). Regulatory Impact Statement: Enhanced Extended Supervision Order. Accessed online at: www.corrections.govt.nz/ data/assets/pdf file/0005/774599/Revised RIS Parole Extended Supervision Orders 3 Nov 14.pdf, date accessed: 28 September 2014.

Equal Justice Project (2012). Is it Better to Be Safe than Sorry? A Comparative Analysis of Preventive Detention Schemes. Presented to the New Zealand Centre of Human Rights Law, Policy and Practice.

Feeley, M. M.; and Simon, J. (1992). The new penology: Notes on the emerging strategy of corrections and its implications. Criminology, 30(4), 449-474.

Finlayson, C. (2012). Public Safety (Public Protection Orders) Bill - Consistency with the New Zealand Bill of Rights Act 1990. Accessed online at: ndhadeliver.natlib.govt.nz/ArcAggregator//arcView/resource/IE26146201//h ttp://www.justice.govt.nz/policy/constitutional-law-and-human- 


\section{rights/human-rights/bill-of-rights/public-safety-public-protection-orders-bill,}

date accessed: 5 April 2014.

Finlayson, C. (2014). Report of the Attorney-General under the Bill of Rights Act 1990 on the Parole (Extended Supervision Orders) Amendment Bill. Wellington, New Zealand; New Zealand Government.

Floud, J.; and Young, W. (1981). Dangerousness and Criminal Justice. London, United Kingdom; Heinemann.

Garland, D. (2001). The Culture of Control. Oxford, United Kingdom: Oxford University Press.

Gavaghan, C.; Snelling, J.; and McMillan, J. (2014). Better and Better and Better? A Legal and Ethical Analysis of Preventive Detention in New Zealand. Dunedin, New Zealand; The New Zealand Law Foundation and University of Otago.

Hall, G. G. (2014). Sentencing Law and Practice ( $3^{\text {rd }}$ ed.). Wellington, New Zealand; LexisNexis New Zealand.

Hall, G. G., and O'Driscoll, S. (2002). The New Sentencing and Parole Acts. Wellington, New Zealand; New Zealand Law Society.

Haney, C. (2002). The Psychological Impact of Incarceration: Implications for Post Prison Adjustment. Washington, DC; U.S. Department of Health and Human Services.

Hannah-Moffat, K. (2005). Criminogenic needs and the transformative risk subject: Hybridization of risk/need in penalty. Punishment and Society, 7(1), 29-51.

Hannah-Moffat, K. (2013). Actuarial sentencing: An "unsettled" proposition. Justice Quarterly, 30(2), 270-296. 
Harrison, K. (2011). Dangerousness, Risk and the Governance of Serious Sexual and Violent Offenders. Abingdon, United Kingdom; Routledge.

Hurd, C. (2008). The Changing Face of Preventive Detention in New Zealand. Presentation to the Sentencing Conference, National Judicial Conference of Australia/ANU College of Law.

Institute for Criminal Policy Research (no date). World Prison Brief: New Zealand. Accessed online at: www.prisonstudies.org/country/new-zealand, date accessed: 4 January 2017.

James, Wells and Lee v. The United Kingdom, 25119/09 57715/09 57877/09 HEJUD [2012] ECHR 1706.

Kansas v Hendricks, 521 US 346 (1997).

Keyzer, P.; and Blay, S. (2006). Double punishment? Preventive detention schemes under Australian legislation and their consistency with international law: The Fardon communication. Melbourne Journal of International Law, 7(2), 407424.

Keyzer, P.; and McSherry, B. (2015). The preventive detention of sex offenders: Law and practice. University of New South Wales Law Journal, 38(2), 792822.

M v Germany, 19395/04 (ECHR 2009).

Magee, H. (2013). The criminal character: a critique of contemporary risk assessment and preventive detention of criminal offenders in NZ. Auckland University Law Review, 19, 76-98.

Martinson, R. (1974). What works? Questions and answers about prison reform. The Public Interest, 35, 22-54. 
McSherry, B. (2013). Managing Fear: The Law and Ethics of Preventive Detention and Risk Assessment. New York, NY; Routledge.

McSherry, B. (2014). Throwing away the key: The ethics of risk assessment for preventive detention schemes. Psychiatry, Psychology and Law, 21(5), 779790.

Meek, J. (1995). The revival of preventive detention in New Zealand 1986-93. Australian and New Zealand Journal of Criminology, 28(3), 225-257.

Monahan, J.; Brodsky, S. L.; and Shan, S. A. (1981). Predicting Violent Behavior: An Assessment of Clinical Techniques. Beverly Hills, CA: Sage Publications.

Parliamentary Debates (Hansard) (1984). Parliamentary Debate on the Criminal Justice Act 1985. Wellington, New Zealand; New Zealand Government.

Penal Policy Review Committee (1981). Report of the Penal Policy Review Committee 1981: Presented to the Minister of Justice. Wellington, New Zealand; New Zealand Government.

Phelps, M.S. (2011). Rehabilitation in the punitive era: The gap between rhetoric and reality in U.S. prison programs. Law and Society Review, 45(1), 33-68.

Pratt, J. (1995). Dangerousness, risk and technologies of power. Australian and New Zealand Journal of Criminology, 28(1), 3-31.

Pratt, J. (1996). Governing the dangerous: An historical overview of dangerous offender legislation. Social and Legal Studies, 5(1), 21-36.

Pratt, J. (1997). Governing the Dangerous. Sydney, Australia; The Federation Press.

Pratt, J. (1998). The rise and fall of homophobia and sexual psychopath legislation in postwar society. Psychology, Public Policy, and Law, 4(1-2), 25-49. 
Pratt, J. (2007). Penal Populism. Abingdon, United Kingdom; Routledge.

Pratt, J. (2008). When penal populism stops: Legitimacy, scandal and the power to punish in New Zealand. Australian and New Zealand Journal of Criminology, 41(3), 364-383.

Pratt, J. (2013). A Punitive Society: Falling Crime and Rising Imprisonment in New Zealand. New Zealand; BWB Texts.

Pratt, J. and Clark M. (2005). Penal populism in New Zealand. Punishment \& Society 7.3: 303-322.

Pratt, J. and Treacher, P. (1988). Law and order and the 1987 New Zealand Election. Australian and New Zealand Journal of Criminology, 21(4), 253-268.

$R v$ Peta, CA 48/06 (NZCA, 2007).

Roberts, J.V. (2003). Sentencing reform in New Zealand: An analysis of the Sentencing Act 2002. Australian and New Zealand Journal of Criminology, $36(3), 249-271$.

Roberts, N. (2016). Referendums - Citizens-initiated referendums ( $2^{\text {nd }}$ ed.). Te Ara The Encyclopaedia of New Zealand. Accessed online at: www.TeAra.govt.nz/en/referendums/page-6, date accessed: 30 June 2014.

Roper, C (1987) Report of the Ministerial Committee of Inquiry into Violence (Roper Report). Wellington: Government Printer.

Simon, J. (2005). Reversal of fortune: The resurgence of individual risk assessment in criminal justice. Annual Review of Law and Social Sciences, 1(1), 397-421. 
Simon, J. (2007). Governing Through Crime: How the War on Crime Transformed American Democracy and Created a Culture of Fear. Oxford, United Kingdom; Oxford University Press.

Statistics New Zealand (no date). The Official Yearbook: 2012 - The Numbers of Justice. Accessed online at: www.stats.govt.nz/browse for stats/snapshotsof-nz/yearbook/society/crime/justice.aspx, date accessed: 20 September 2015.

Steadman, H. J. (1973). Follow-up on Baxstrom patients returned to hospitals for the criminally insane. American Journal of Psychiatry, 130(3), 317-319.

Steadman, H. J. (1980). The right not to be a false positive: Problems in the application of the dangerousness standard. Psychiatric Quarterly, 52(2), 8499.

Steadman, H. J.; and Cocozza, J. J. (1980). The prediction of dangerousnessBaxtrom: A case study. In Cooke, G. (ed) The Role of the Forensic Psychologist, 204-215.

Taunoa v Attorney-General [2007] NZSC [70]

Vess, J. (2005). Preventive detention versus civil commitment: Alternative policies for public protection in New Zealand and California. Psychiatry, Psychology and Law, 12(2), 357-366.

Von Hirsch, A. (1976). Doing Justice: The Choice of Punishments. New York, NY; Hill and Wang.

Wacquant, L. (2001). The penalisation of poverty and the rise of neo-liberalism. European Journal on Criminal Policy and Research, 9(4), 401-412. 
Wilson, A. (2008). Successful Prisoner Reentry: An Analysis of the Most Important Variables. Master of Criminal Justice Thesis, University of Western Australia. 


\section{Appendix A - Crime Trends in New Zealand}

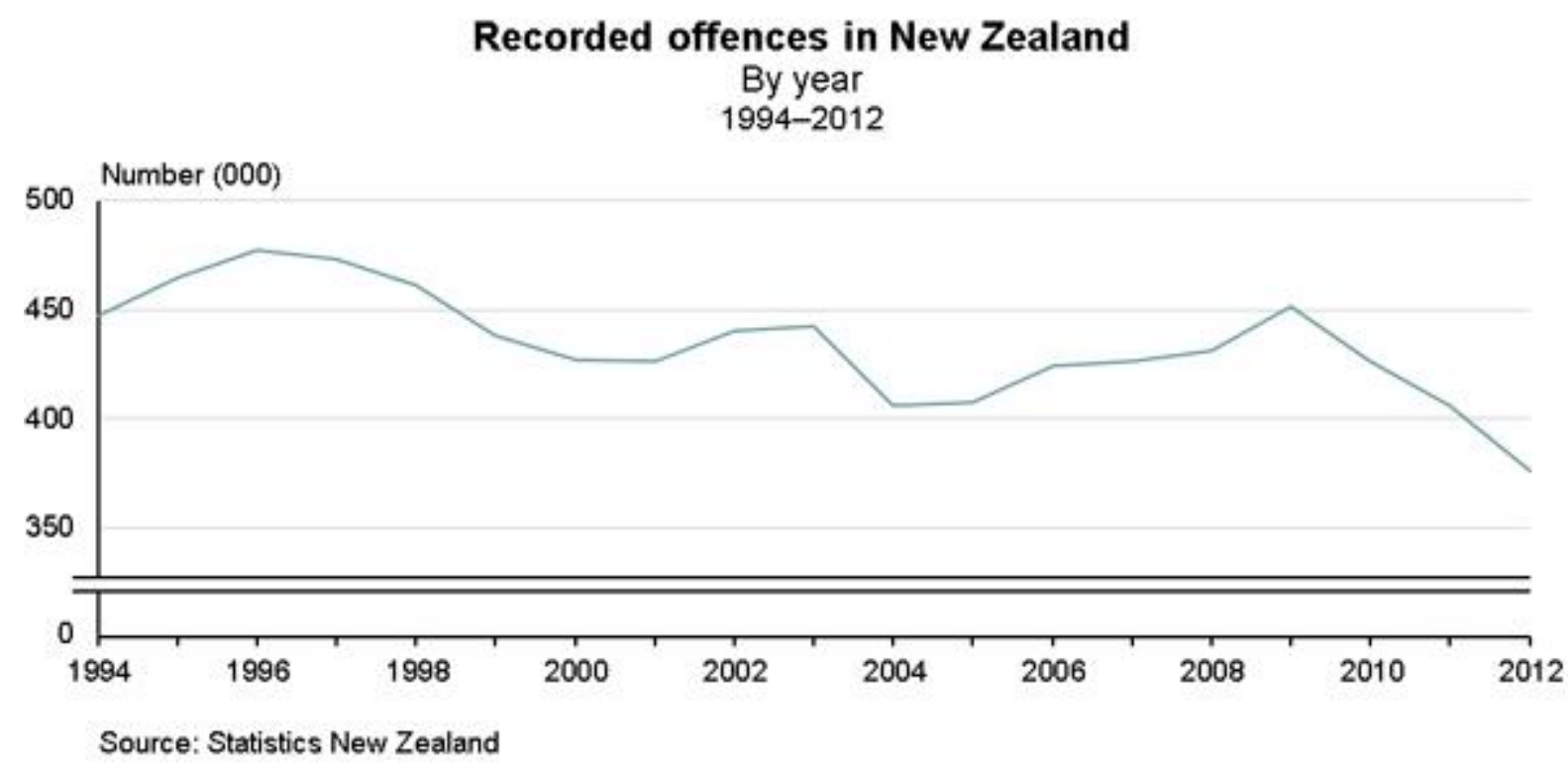

Figure 1: Official New Zealand crime statistics

Figure 1 shows that since 1994, the highest number of recorded offences was in 1996, when over 477,500 offences were recorded. There was another peak in 2009 , with over 450,000 offences. Since then, recorded crime has decreased steadily. By 2012, it was 17 percent lower than 2009. 


\section{Appendix B - Ethics Approval}

\begin{tabular}{l|l}
\hline TO & Geetanjali Swati Bhim \\
\hline COPY TO & \\
\hline FROM & Dr Rhonda Shaw \\
\hline DATE & 29 September 2012 \\
\hline PAGES & 1 \\
\hline & \\
\hline SUBJECT & $\begin{array}{l}\text { Ethics Approval: No. 19450 } \\
\text { Title: 'The Ethics and Dilemmas of Preventive Detention' }\end{array}$
\end{tabular}

Thank you for your request for ethical approval, which has been considered by the Social and Cultural Studies Human Ethics Sub-Committee. Your ethics application has been approved. The approval period is to October 2014. If your data collection has not been completed by this date please contact the Ethics Committee.

Best wishes,

Signature redacted

Dr Rhonda Shaw

Convener, SACS Human Ethics Committee 